\title{
Effects of simvastatin on iNOS and caspase-3 levels and oxidative stress following smoke inhalation injury
}

\author{
RONG-QIANG YANG ${ }^{1}$, PENG-FEI GUO ${ }^{1}$, ZHAO MA $^{2}$, CHENG CHANG $^{2}$, QING-NAN MENG $^{1}$, \\ YA GAO $^{1}$, IMRAN KHAN ${ }^{1}$, XIAO-BO WANG $^{1}$ and ZHENG-JUN CUI ${ }^{1}$ \\ ${ }^{1}$ Department of Burn and Repair Reconstruction Surgery, The First Affiliated Hospital of Zhengzhou University; \\ ${ }^{2}$ The School of Basic Medical Science of Zhengzhou University, Zhengzhou, Henan 450052, P.R. China
}

Received September 28, 2019; Accepted June 12, 2020

DOI: $10.3892 / \mathrm{mmr} .2020 .11413$

\begin{abstract}
The overexpression of inducible nitric oxide synthase (iNOS) induces cell apoptosis through various signal transduction pathways and aggravates lung injury. Caspase-3 is an important protein in the apoptotic pathway and its activation can exacerbate apoptosis. Simvastatin, a hydroxymethyl glutaryl-A reductase inhibitor, protects against smoke inhalation injury by inhibiting the synthesis and release of inflammatory factors and decreasing cell apoptosis. Following the establishment of an animal model of smoke inhalation injury, lung tissue and serum were collected at different time points and the protein and mRNA expression of iNOS and caspase- 3 in lung tissue by immunochemistry, western blot and reverse transcription-quantitative polymerase chain reaction, the malondialdehyde (MDA) content and superoxide dismutase (SOD) activity in lung tissue and serum were analyzed using thiobarbituric acid method and the WST-1 method. The results were statistically analyzed. The lung tissues of the rats in the saline group and the low-, middle- and high-dose groups exhibited clear edema and hemorrhage, and had significantly higher pathological scores at the various time points compared with the rats in the control group $(\mathrm{P}<0.05)$. Furthermore, lung tissue and serum samples obtained from these four groups had significantly higher mRNA and protein expression levels of iNOS and caspase-3 $(\mathrm{P}<0.05)$, significantly lower SOD activity and higher MDA content $(\mathrm{P}<0.05)$. Compared with the saline group, the low-, middle- and high-dose groups had significantly lower pathological scores $(\mathrm{P}<0.05)$, significantly lower mRNA and protein expression levels of iNOS, caspase-3 and MDA content in lung tissues $(\mathrm{P}<0.05)$ and significantly higher SOD activity in lung tissues and serum. The middle- and
\end{abstract}

Correspondence to: Dr Zheng-Jun Cui, Department of Burn and Repair Reconstruction Surgery, The First Affiliated Hospital of Zhengzhou University, 1 Jianshe East Road, Zhengzhou, Henan 450052, P.R. China

E-mail: 13937197452@163.com

Key words: smoke inhalation injury, simvastatin, inducible nitric oxide synthase, caspase- 3 , oxidative stress high-dose groups had significantly lower pathological scores $(\mathrm{P}<0.05)$, significantly decreased iNOS and caspase-3 mRNA and protein expression in lung tissues, significantly higher SOD activity in lung tissues and serum and a significantly lower MDA content $(\mathrm{P}<0.05)$ compared with the low-dose group. With the exception of SOD activity in lung tissues at 24 and $72 \mathrm{~h}$ and MDA content in serum at $48 \mathrm{~h}$, no significant differences were observed between the middle- and high-dose groups. The present study demonstrated that there was an association between the therapeutic effect and dosage of simvastatin within a definitive range. In rats with smoke inhalation injury, simvastatin inhibited iNOS and caspase-3 expression in lung tissues and mitigated oxidative stress, thereby exerting a protective effect. In addition, the effect and dose were associated within a definitive range.

\section{Introduction}

Smoke inhalation injury, a common complication in patients with thermal injuries, particularly those with flame burns, is an important cause of increased mortality in patients with burns (1-3). According to the current view, thermal injury directly induces respiratory tract damage and the particles and chemicals contained in smoke strongly exacerbate the progression of inhalation injury (4). When various particles and chemical components of smoke, such as dust particles and $\mathrm{CO}$ or $\mathrm{SO}_{2}$ enter the respiratory tract, these components induce the infiltration of massive numbers of inflammatory cells and the subsequent release of inflammatory mediators into the respiratory tract, stimulating a cascade of stress reactions $(5,6)$. The available evidence consistently indicates that the particulate matter in smoke induces direct thermal damage and triggers cytokine production by alveolar macrophages, resulting in a neutrophil-mediated inflammatory response and activation of the NF- $\mathrm{kB}$ signal pathway, which contributes to lung injury (7). In addition, previous studies have demonstrated that inducible nitric oxide synthase (iNOS) serves a role in smoke inhalation injury by promoting the apoptosis of alveolar epithelial cells via various signal transduction pathways (8-10). Numerous components of smoke are strong oxidants that can disrupt the redox balance in the body. In addition, the excessive accumulation of inflammatory cells in the lungs leads to the production of excessive reactive oxygen species (ROS), 
further aggravating the tissue damage caused by oxidative stress (11). The activation of neutrophils and the enhancement of arachidonic acid metabolism following inhalation injury leads to an increase in the production of oxygen free radicals and subsequently causes an increase in the consumption of antioxidant substances (12). Polyunsaturated fatty acids subsequently undergo overoxidation, causing cell damage and accelerating apoptosis, resulting in a decrease in superoxide dismutase (SOD) activity and an increase in malondialdehyde (MDA) content following smoke inhalation injury (13).

Simvastatin, a widely used cholesterol-lowering drug, can substantially reduce the incidence of cardiovascular events in patients with hyperlipidemia $(14,15)$. Based on clinical analyses, simvastatin also exerts anti-inflammatory, antioxidant and immunomodulatory effects independent of its lipid-lowering effect (16-18). Some clinical studies have reported that patients with inhalation injury who took statins long-term usually recovered faster (19). The purpose of the present study was to investigate the potential of statins in the treatment of patients with inhalation injury, resolve the underlying mechanisms by which they inhibit the progression of the disease and to evaluate the protective effect exerted by simvastatin against smoke inhalation injury in rats.

\section{Materials and methods}

Ethics. The present study was approved by the Animal Care and Use Committee of Zhengzhou University (Henan, China) and conducted in accordance with the National Institutes of Health Guide for the Care and Use of Laboratory Animals (20).

A total of 75 male Sprague-Dawley (SD) rats (aged 6-8 weeks, weighing 220-250 g) were provided by the Laboratory Animal Center of Henan Province [animal certification: SCXK (Yu) 2015-0004]. The rats were housed under standard conditions, at a temperature of $20-22^{\circ} \mathrm{C}$ and $40-60 \%$ humidity, with a $12-\mathrm{h}$ light/dark cycle and free access to water and food. The rats were acclimated for 1 week before the experiments were performed. The rats were randomly divided into five groups: A control group (uninjured and untreated, $\mathrm{n}=15$ ), a saline group (treated with saline following smoke exposure, $n=15$ ), a low-dose group (treated with $25 \mathrm{mg} / \mathrm{kg}$ simvastatin following smoke exposure, $\mathrm{n}=15$ ), a middle-dose group (treated with $50 \mathrm{mg} / \mathrm{kg}$ simvastatin following smoke exposure, $\mathrm{n}=15$ ) and a high-dose group (treated with $100 \mathrm{mg} / \mathrm{kg}$ simvastatin following smoke exposure, $\mathrm{n}=15$ ). Within the first $30 \mathrm{~min}$ following smoke exposure, rats in the low-, middle- and high-dose groups were administered intragastric simvastatin based on their body weight at $12-\mathrm{h}$ intervals and rats in the saline group were administered an equal volume of normal saline.

Generation of an animal model of smoke inhalation injury. A total of 15 rats were randomly assigned to the control group. The remaining 60 rats were exposed to smoke, which caused smoke inhalation lung injury. The establishment of an animal model of smoke inhalation injury was based on previous experiments and relevant literature $(21,22)$. A temperature monitor was installed inside a special glass container with a length, width and height of 50,35 and $45 \mathrm{~cm}$, respectively, to detect the temperature. Then, $100 \mathrm{~g}$ of dry pine chips and $30 \mathrm{ml}$ of kerosene were thoroughly mixed in a pot equipped with a heating device at the bottom and the heating device was switched on $5 \mathrm{~min}$ before the experiment. The smoke was wafted from the pot to the glass container using an air blower. After the glass container was loaded with smoke, six rats were arranged in a $30 \times 20 \times 15 \mathrm{~cm}$ wire cage and placed into the container. Following a 2-min exposure, the rats were removed from the container and maintained in a normal environment for $5 \mathrm{~min}$. The above procedure was repeated three times, resulting in a cumulative smoke inhalation duration of $6 \mathrm{~min}$. Within the first $30 \mathrm{~min}$ following induction of smoke inhalation injury, the low-, middle- and high-dose groups were administered 25,50 and $100 \mathrm{mg} / \mathrm{kg}$ intragastric simvastatin, respectively, according to their weight, every $12 \mathrm{~h}$ (23), while the saline group was administered an equal volume of normal saline. At 24, 48 and $72 \mathrm{~h}$ following injury, a $10 \%$ solution of chloral hydrate was administered for anesthesia via intraperitoneal injection at $300 \mathrm{mg} / \mathrm{kg}$ according to their weight. None of the rats exhibited signs of peritonitis, pain or discomfort following administration of chloral hydrate. Blood samples were collected through puncture of the left ventricle, allowed to clot for $60 \mathrm{~min}$ and centrifuged at $3,000 \mathrm{x} \mathrm{g} / \mathrm{min}$ at $4^{\circ} \mathrm{C}$ for $10 \mathrm{~min}$. At that time point, the weight of each rat was reduced by 10-20 g compared with their previous weights; the maximum percentage of weight loss that was observed in the rats from start to endpoint was 7.3\%. Rats were euthanized by exsanguination under anesthesia and the volume of blood collected by exsanguination was $12-17 \mathrm{ml}$. The lack of a heartbeat, respiratory arrest, absent nerve reflex and muscle relaxation were the parameters used to confirm death before further experiments. The left lungs from the rats were removed for pathological examination and scoring. The mRNA levels of iNOS and caspase-3 in the upper lobes of the right lungs were measured by reverse transcription-quantitative (RT-q) PCR and the protein levels of iNOS and caspase- 3 in the middle lobes of the right lungs were measured by western blotting. The activity of SOD and the content of MDA in serum samples and lung tissues obtained from the lower lobes of the right lungs were measured.

Pathological examination and scoring. Lung tissues were fixed in $10 \%$ formalin at room temperature for $24 \mathrm{~h}$, dehydrated through an ascending series of ethanol solutions (70, 80,95 and $100 \%$ alcohol), embedded in paraffin, sectioned to $5-\mu \mathrm{m}$ thickness and stained with hematoxylin at room temperature for $5 \mathrm{~min}$ and followed by eosin at room temperature for $2 \mathrm{~min}$. Then, two experienced pathologists evaluated the tissue morphology under a light microscope (magnification, $\mathrm{x} 200$ ) in a blinded manner. The severity of the observed lung injuries was scored according to the following criteria: Edema, neutrophil infiltration, hemorrhage and hyaline membrane formation. The severity of lung injury was scored from 0 to 4 as follows: 0 , no injury; 1 , mild injury; 2 , moderate injury; 3 , severe injury; and 4, most severe lung injury. Together, five randomly selected sections from each pathological specimen were observed and scored and these scores were added to obtain the lung histopathological score.

Immunohistochemistry. The immunohistochemical analysis of iNOS and caspase-3 expression in lung tissues was 
performed in a two-step manner. Sections were deparaffnized at $60^{\circ} \mathrm{C}$ for $1 \mathrm{~h}$, washed in xylene twice for $10 \mathrm{~min}$ and rehydrated in a descending alcohol series. Antigen retrieval was performed for $12 \mathrm{~min}$ in a microwave and the tissues were then incubated with primary antibody (iNOS, 1:50; cat. no. ab3523 Abcam and caspase-3, 1:50; cat. no. ab4051 Abcam) at room temperature for $16 \mathrm{~h}$, followed by incubation with horseradish peroxidase-conjugated goat anti-rabbit immunoglobulin $\mathrm{G}$ ( $\mathrm{IgG}$ ) secondary antibody for $1 \mathrm{~h}$ (1:2,000, cat. no. TA130024 OriGene Technologies, Inc.) at room temperature. The tissues were then stained with diaminobenzidine at room temperature for $5 \mathrm{~min}$. The control sections were subjected to the same procedure but without primary antibody incubation. The expression levels of iNOS and caspase-3 in lung tissues were evaluated by two experienced pathologists under a light microscope (magnification, x400). A cell with a brown cytoplasm or a brown nucleus was considered immunoreactive. All immunoreactive cells in at least five sections from each specimen were counted and the percentage of positive cells was determined, expression levels were quantified using Image-Pro Plus 6.0 (Media Cybernetics, Inc.).

$R T-q P C R$. The mRNA expression levels of iNOS and caspase-3 were measured using RT-qPCR. Total RNA was extracted from the upper lobe of the right lung (10-15 g) from each rat using TRIzol ${ }^{\circledR}$ reagent (Invitrogen; Thermo Fisher Scientific, Inc.) according to the manufacturer's protocol. The concentration of RNA was determined using a nanodrop ND-1000 spectrophotometer (Thermo Fisher Scientific, Inc.). RNA $(2 \mu \mathrm{g})$ was reverse transcribed into cDNA for $5 \mathrm{~min}$ at $70^{\circ} \mathrm{C}$ and $5 \mathrm{~min}$ at $4^{\circ} \mathrm{C}$ using a First-strand cDNA Synthesis kit (Promega Corporation), according to the manufacturer's protocol. qPCR was performed using a qPCR Master mix (New England Biolabs, Inc.) and 96-well optical reaction plates and the CFX96 Real-Time PCR detection system (Bio-Rad Laboratories, Inc.). The following PCR conditions were used: Predenaturation at $95^{\circ} \mathrm{C}$ for $60 \mathrm{sec}$ followed by 40 cycles of denaturation at $95^{\circ} \mathrm{C}$ for $15 \mathrm{sec}$ and extension at $60^{\circ} \mathrm{C}$ for $45 \mathrm{sec}$, according to the manufacturer's protocol. All experiments were performed four times. The primers were provided by Sangon Biotech (Shanghai) Co., Ltd. The primer sequences for GAPDH were: Forward: 5'-AACATC CAGAGCTTGACGGTG-3' and reverse: 5'-TCTTGACCA TCCTTGAGAGTGG-3' and the primer sequences for iNOS were forward: 5'-AACCCAAGGTCTACGTTCAAG-3' and reverse: 5'-AAAGTGGTAGCCACATCCCG-3'. The primer sequences for caspase-3 were forward: 5'-TGGTTCATCCAG TCGCTTTGT-3' and reverse: 5'-CAAATTCTGTTGCCA CCTTTCG-3'. Relative gene expression levels were calculated using the relative quantification $2^{-\Delta \Delta \mathrm{Cq}}$ method and normalized to GAPDH (24).

Western blotting. The protein expression levels of iNOS and caspase-3 in lung tissues were evaluated using western blotting. The proteins from the middle lobe tissue from the right lung of each rat were extracted using RIPA lysis buffer (Biotechwell) supplemented with phenylmethylsulfonyl fluoride and the supernatant was collected. The protein concentration was measured with a Bicinchoninic Acid
Assay kit (Biotechwell: http://www.biotechwell.com). Then, $40 \mu \mathrm{g}$ protein/lane was separated by $12 \%$ SDS-PAGE. The separated proteins were subsequently transferred onto PVDF membranes (EMD Millipore) and blocked for $2 \mathrm{~h}$ at room temperature with 5\% non-fat milk solution. The membranes were incubated with a rabbit anti-iNOS polyclonal antibody (1:200, cat. no. ab3523 Abcam), rabbit anti-caspase-3 polyclonal antibody (1:100, cat. no. ab4051 Abcam), or rabbit anti- $\beta$-actin polyclonal antibody (1:500, cat. no. ab6276 Abcam) in tris-buffered saline and Tween 20 (0.1\%) TBST overnight at $4^{\circ} \mathrm{C}$. The membranes were then incubated with horseradish peroxidase-conjugated goat anti-rabbit $\mathrm{IgG}$ secondary antibody (1:2,000, cat. no. TA130024 OriGene Technologies, Inc.) for $1.5 \mathrm{~h}$ at room temperature. The resulting bands were detected with an enhanced chemiluminescence detection system, using the Pierce ${ }^{\mathrm{TM}}$ ECL Western Blotting Substrate (Bio-Rad Laboratories, Inc.). Protein expression was semi-quantified using Image-Pro Plus version 6.0 software (Media Cybernetics, Inc.) with $\beta$-actin as the loading control.

Measurement of SOD activity and MDA content. Using precooled saline as the medium, homogenates of the right lung lower lobes were centrifuged at 3,000 x g/min for $15 \mathrm{~min}$ at $4^{\circ} \mathrm{C}$ and the supernatants were collected. The assays were performed according to the manufacturer's instructions. The MDA content in the supernatant and serum was measured using the thiobarbituric acid method (Nanjing Jiancheng Bioengineering Institute). The absorbance values used for the MDA measurements were obtained at $532 \mathrm{~nm}$ by microplate reader and converted to $\mathrm{nmol} / \mathrm{mg}$ protein or $\mathrm{nmol} / \mathrm{ml}$. SOD activity in the supernatant and serum was measured using the WST-1 method (Nanjing Jiancheng Bioengineering Institute). The absorbance values used for the measurements of SOD activity in supernatant and serum were obtained at $450 \mathrm{~nm}$ by microplate reader and converted to $\mathrm{U} / \mathrm{mg}$ protein or $\mathrm{U} / \mathrm{ml}$.

Statistical analysis. All data were expressed as the mean \pm standard deviation. The data were subjected to statistical analyses using SPSS version 22 software (IBM, Corp). The homogeneity of variance was first determined using Levene's test. One way Analysis of variance was used for overall comparisons between groups and Tukey's post hoc test when the homogeneity of variance assumption was met or by the Games-Howell test when the homogeneity of variance assumption was not met. $\mathrm{P}<0.05$ was considered to indicate a statistically significant difference.

\section{Results}

Pathological examination and scores. The inflammatory response was significantly reduced following the administration of simvastatin. Higher pathological scores were obtained in the saline and low-, middle- and high-dose groups compared with the control group $(\mathrm{P}<0.05)$. In addition, the pathological scores of the low-, middle- and high-dose groups were lower compared with the saline group $(\mathrm{P}<0.05)$. Additionally, the scores of the middle- and high-dose groups were lower compared with the low-dose group $(\mathrm{P}<0.05)$. The difference between the middle- and high-dose groups was 


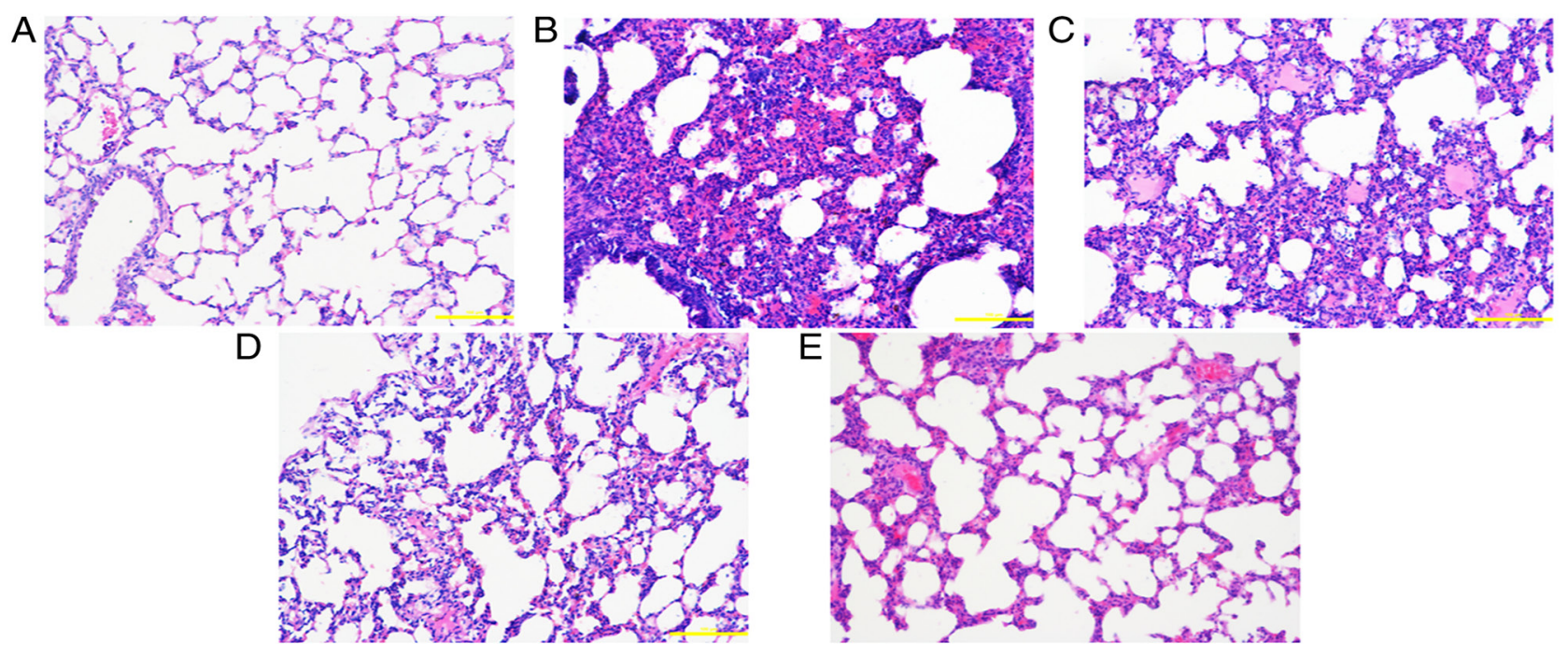

Figure 1. Pathological changes in lung tissue at $24 \mathrm{~h}$. (A) Control group: The alveolar structure of lung tissues from the control group was complete, with uniform alveolar intervals and an alveolar cavity showing no evident inflammatory cell infiltration or edema. Following exposure to smoke, lung tissue edema was accompanied by varying degrees of exudation, alveolar septal edema, hemorrhage and inflammatory cell infiltration. The alveolar cavity contained a large number of inflammatory cells and a large amount of erythrocyte exudation. (B) Saline group, (C) low-dose group, (D) middle-dose group and (E) high-dose group. Scale bars, $200 \mu \mathrm{m}$; magnification, x200; hematoxylin and eosin staining.

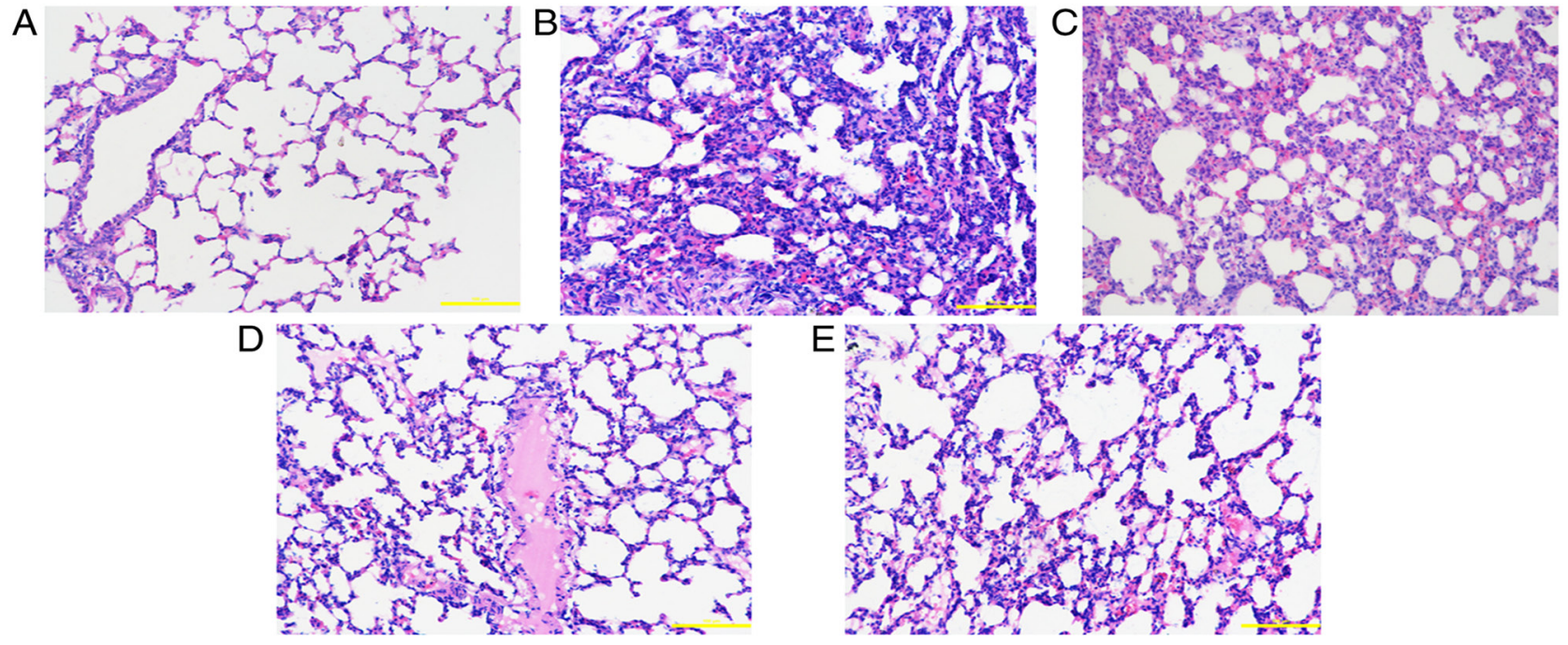

Figure 2. Pathological changes in lung tissue at $48 \mathrm{~h}$. (A) Control group: The alveolar structure of lung tissues from the control group was complete, with uniform alveolar intervals and an alveolar cavity showing no evident inflammatory cell infiltration or edema. Following exposure to smoke, lung tissue edema was accompanied by varying degrees of exudation, alveolar septal edema, hemorrhage and inflammatory cell infiltration. The alveolar cavity contained a large number of inflammatory cells and a large amount of erythrocyte exudation. (B) Saline group, (C) low-dose group, (D) middle-dose group and (E) high-dose group. Scale bars, $200 \mu \mathrm{m}$; magnification, x200; hematoxylin and eosin staining.

non-significant ( $\mathrm{P}>0.05$; Figs. 1, 2 and 3; statistical data not shown).

Immunohistochemistry. Based on immunohistochemical analysis, iNOS (Figs. 4, 5 and 6; statistical data not shown) and caspase-3 (Figs. 7, 8 and 9; statistical data not shown) expression levels were higher in the saline and theablr low-, medium- and high-dose groups compared with the control group $(\mathrm{P}<0.05)$; lower in the low-, middle- and high-dose groups compared with the saline group $(\mathrm{P}<0.05)$; and lower in the middle- and high-dose groups compared with the low-dose group $(\mathrm{P}<0.05)$. The difference between the middle- and high-dose groups was non-significant $(\mathrm{P}>0.05)$.
$R T$ - $q P C R$. RT-qPCR revealed that iNOS and caspase- 3 mRNA expression levels were lower in the low-, middle- and high-dose groups compared with the saline group $(\mathrm{P}<0.01$ or 0.05$)$ and lower in the middle- and high-dose groups compared with the low-dose group $(\mathrm{P}<0.01$ or 0.05$)$. The difference between the middle- and high-dose groups was not significant $(\mathrm{P}>0.05$; Figs. 10, 11 and 12).

Western blot analysis. Western blot analysis demonstrated that the protein levels of iNOS and caspase-3 were higher in the saline, low-dose, middle-dose and high-dose groups compared with the control group $(\mathrm{P}<0.01$ or $\mathrm{P}<0.05)$. Additionally, the protein levels were lower in the low-, middle- and high-dose 

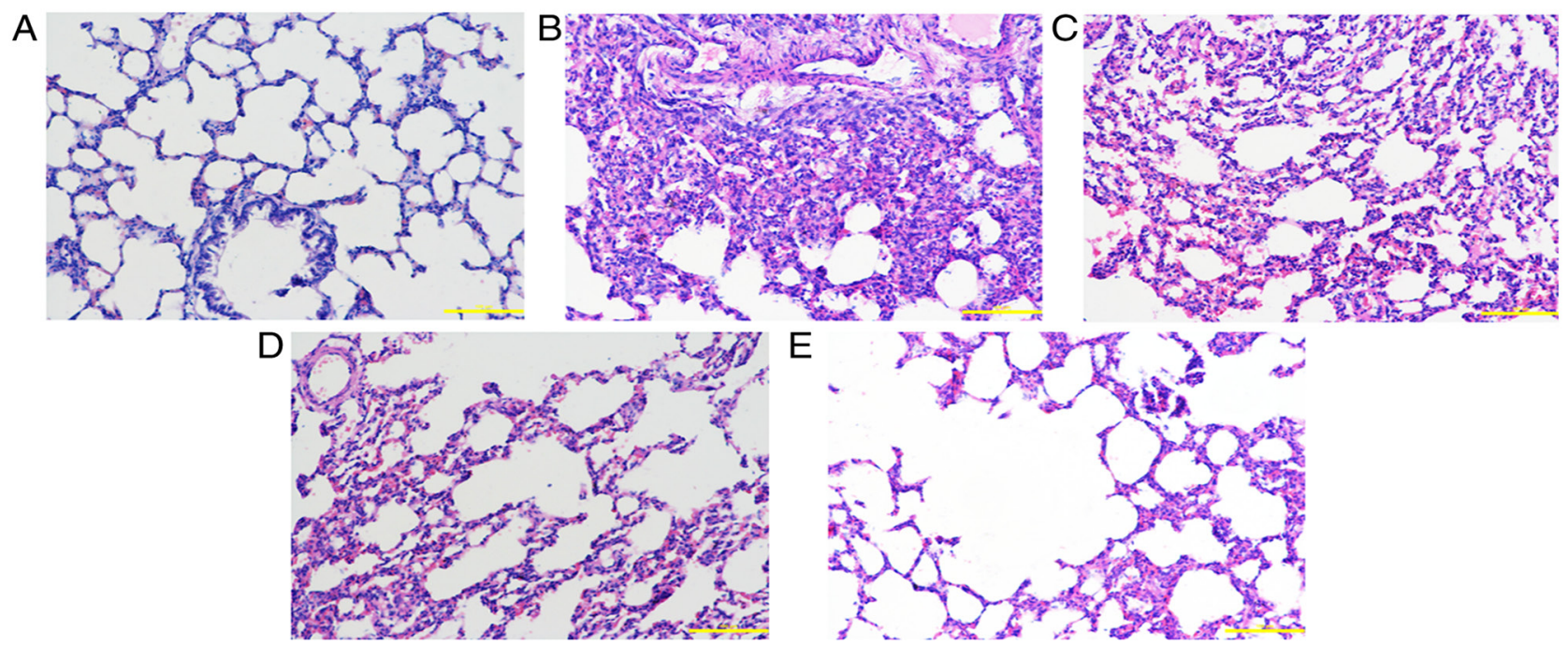

Figure 3. Pathological changes in lung tissue at $72 \mathrm{~h}$. (A) Control group: The alveolar structure of lung tissues from the control group was complete, with uniform alveolar intervals and an alveolar cavity showing no evident inflammatory cell infiltration or edema. Following exposure to smoke, lung tissue edema was accompanied by varying degrees of exudation, alveolar septal edema, hemorrhage and inflammatory cell infiltration. The alveolar cavity contained a large number of inflammatory cells and a large amount of erythrocyte exudation. (B) Saline group, (C) low-dose group, (D) middle-dose group and (E) high-dose group. Scale bars, $200 \mu \mathrm{m}$; magnification, x200; hematoxylin and eosin staining.
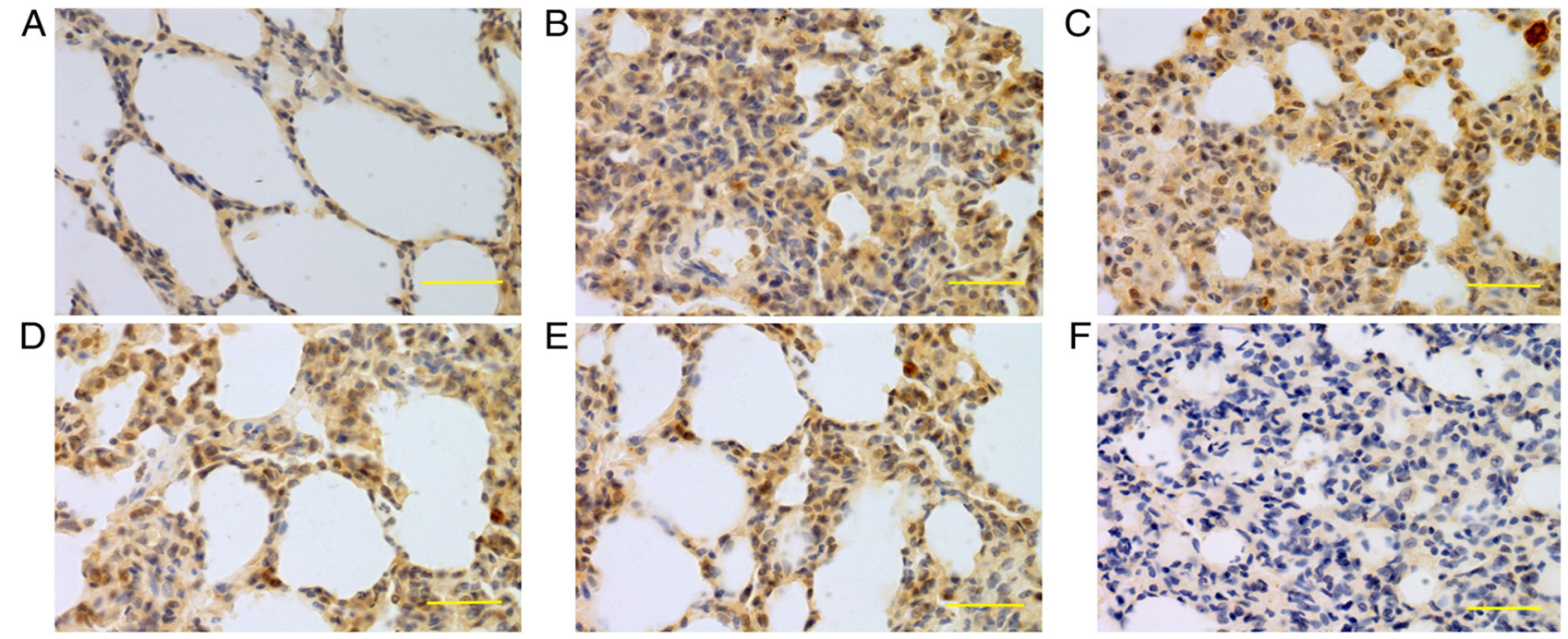

Figure 4. Expression of iNOS in lung tissue at $24 \mathrm{~h}$. iNOS was mainly expressed in bronchial epithelial cells, alveolar epithelial cells and vascular and airway smooth muscle cells. Higher iNOS expression levels were detected in the saline, low-dose, middle-dose and high-dose groups compared with the control group. (A) Control group, (B) saline group, (C) low-dose group, (D) middle-dose group, (E) high-dose group and (F) PBS group. Scale bars, $100 \mu \mathrm{m}$; magnification, x400; DAB staining. iNOS, inducible nitric oxide synthase; DAB, 3,3-diaminobenzidine.

groups compared with the saline group $(\mathrm{P}<0.01$ or $\mathrm{P}<0.05)$ and lower in the middle- and high-dose groups compared with the low-dose group $(\mathrm{P}<0.01$ or $\mathrm{P}<0.05)$. However, no significant difference in the protein levels of iNOS and caspase- 3 was observed between the middle- and high-dose groups $(\mathrm{P}>0.05$; Figs. 13, 14 and 15).

SOD activity and content of MDA. SOD activity in lung tissues and serum was lower in the saline group and the low-, middle- and high-dose groups compared with the control group $(\mathrm{P}<0.05)$; significantly higher in the low-, medium- and high-dose groups compared with the saline group $(\mathrm{P}<0.05)$; and higher in the middle- and high-dose groups compared with the low-dose group $(\mathrm{P}<0.05)$ at 24,48 and $72 \mathrm{~h}$. No significant difference in the SOD activity in lung tissues and serum was observed between the middle- and high-dose groups $(\mathrm{P}>0.05)$, with the exception of at 24 and $72 \mathrm{~h}$ in lung tissues. MDA content in lung tissues and serum was higher in the saline, low-dose, middle-dose and high-dose groups compared with the control group $(\mathrm{P}<0.05)$. Additionally, the MDA content were lower in the low-, middle- and high-dose groups compared with the saline group $(\mathrm{P}<0.05)$ and lower in the middle- and high-dose groups compared with the low-dose group $(\mathrm{P}<0.05)$. The difference between the middle- and high-dose groups was not significant $(\mathrm{P}>0.05)$ except the MDA content in serum at $48 \mathrm{~h}$ (Tables I and II). 

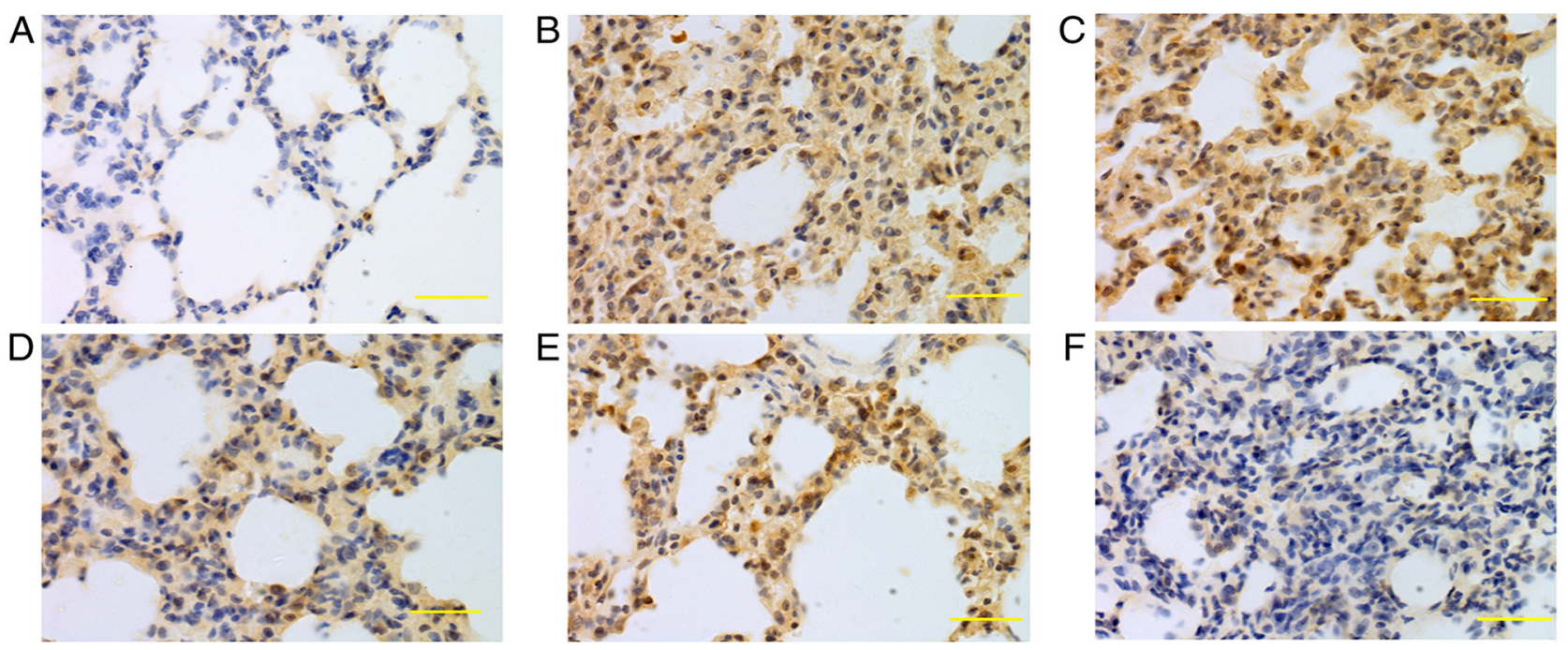

Figure 5. Expression of iNOS in lung tissue at $48 \mathrm{~h}$. iNOS was mainly expressed in bronchial epithelial cells, alveolar epithelial cells and vascular and airway smooth muscle cells. Higher iNOS expression levels were detected in the saline, low-dose, middle-dose and high-dose groups compared with the control group. (A) Control group, (B) saline group, (C) low-dose group, (D) middle-dose group, (E) high-dose group and (F) PBS group. Scale bars, $100 \mu$ m; magnification, x400; DAB staining. iNOS, inducible nitric oxide synthase; DAB, 3,3-diaminobenzidine.
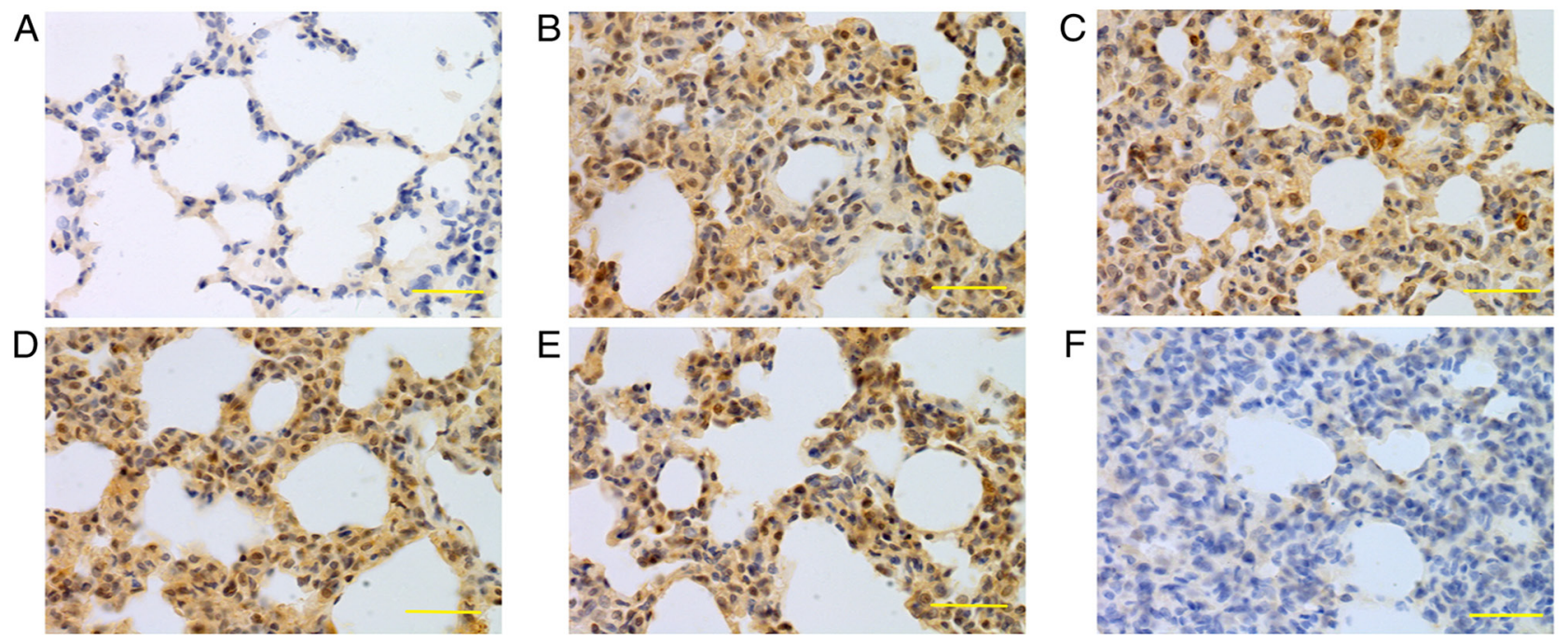

Figure 6. Expression of iNOS in lung tissue at $72 \mathrm{~h}$. iNOS was mainly expressed in bronchial epithelial cells, alveolar epithelial cells and vascular and airway smooth muscle cells. Higher iNOS expression levels were detected in the saline, low-dose, middle-dose and high-dose groups compared with the control group. (A) Control group, (B) saline group, (C) low-dose group, (D) middle-dose group, (E) high-dose group and (F) PBS group. Scale bars, $100 \mu$ m; magnification, x400; DAB staining. iNOS, inducible nitric oxide synthase; DAB, 3,3-diaminobenzidine.

\section{Discussion}

At present, the pathogenesis of inhaled lung injury has yet to be fully elucidated and sufficient evidence from basic research and clinical data is lacking. Previous research on smoke inhalation injury has primarily focused on inflammation and oxidative stress $(25,26)$. For example, one study demonstrated that $\mathrm{NF}-\kappa \mathrm{B}$, tumor necrosis factor (TNF) $\alpha$ and interleukin (IL) 6 serve key roles in smoke inhalation injury (27). During the process of inhalation injury, intracellular quiescent $\mathrm{NF}-\kappa \mathrm{B}$ is activated as a result of the phosphorylation and degradation of inhibitor of NF- $\mathrm{BB}(\mathrm{I} \kappa \mathrm{B})$ and the two of these processes occur when cells are stimulated with various cytokines such as TNF- $\alpha$ and IL-6. Activated NF- $\kappa$ B translocates to the nucleus to regulate the transcription of its target genes, including cytokines, inflammatory mediators, acute phase proteins and inducible effector enzymes $(28,29)$. In previous experimental studies, our research group has demonstrated that simvastatin can significantly reduce the mortality of animal models with smoke inhalation lung injury, alleviate the inflammatory response in lung tissue and significantly reduce the content of $\mathrm{NF}-\kappa \mathrm{B}(30,31)$. Treatment with simvastatin inactivates $\mathrm{NF}-\kappa \mathrm{B}$ by increasing the number of $\mathrm{I} \kappa \mathrm{B}$ molecules, which is regarded as an inhibitor of $\mathrm{NF}-\kappa \mathrm{B}$ and decreases the nuclear $\mathrm{NF}-\kappa \mathrm{B}$ content. The inhibitory effect of statins might be mediated by isoprenoid-induced intracellular signal transduction, which involves several key signaling proteins, including Rho kinase and $\mathrm{I} \kappa \mathrm{B} / \mathrm{NF}-\kappa \mathrm{B}(32)$. 

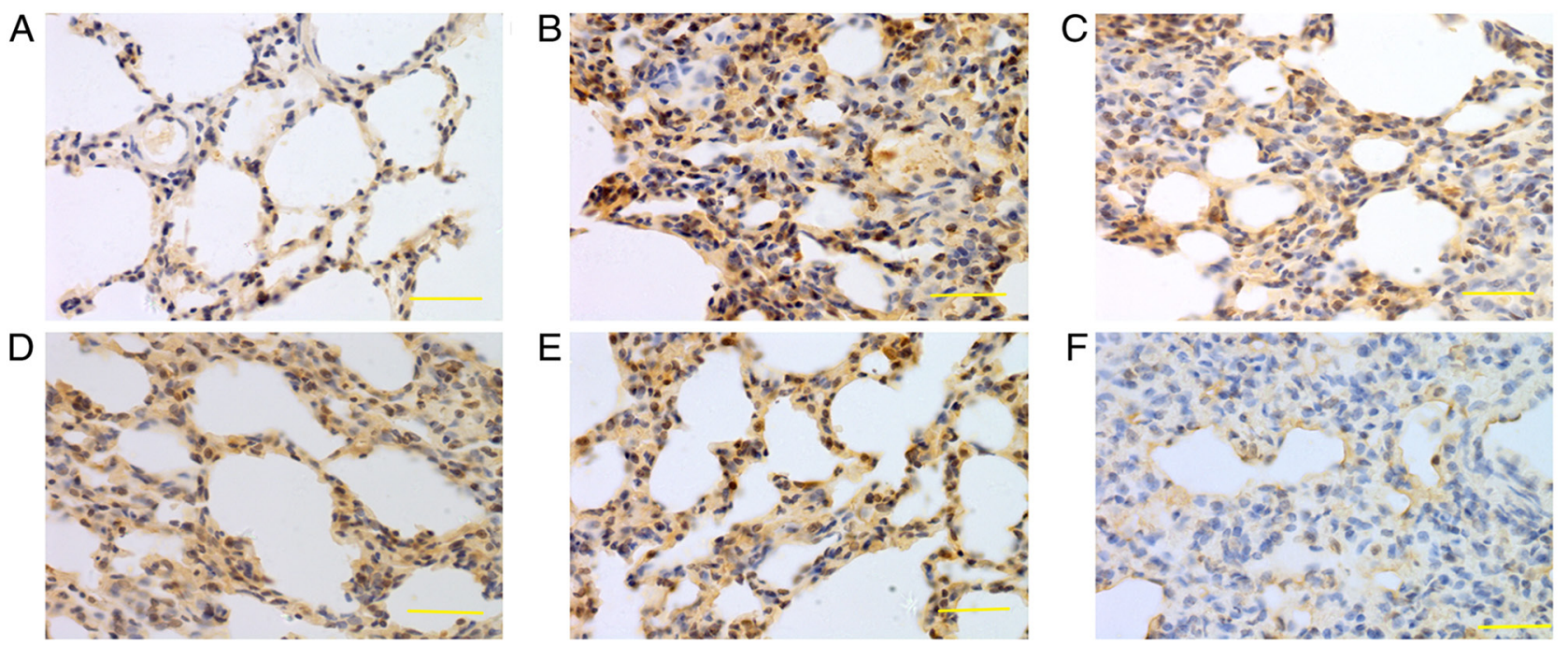

Figure 7. Expression of caspase-3 in lung tissue at $24 \mathrm{~h}$. Caspase-3 was mainly expressed in bronchial epithelial cells, alveolar epithelial cells and vascular and airway smooth muscle cells. The caspase-3 expression levels in the saline, low-, middle- and high-dose groups were higher compared with the normal group. (A) Control group, (B) saline group, (C) low-dose group, (D) middle-dose group, (E) high-dose group and (F) PBS group. Scale bars, $100 \mu \mathrm{m}$; magnification, x400; DAB staining. DAB, 3,3-diaminobenzidine.
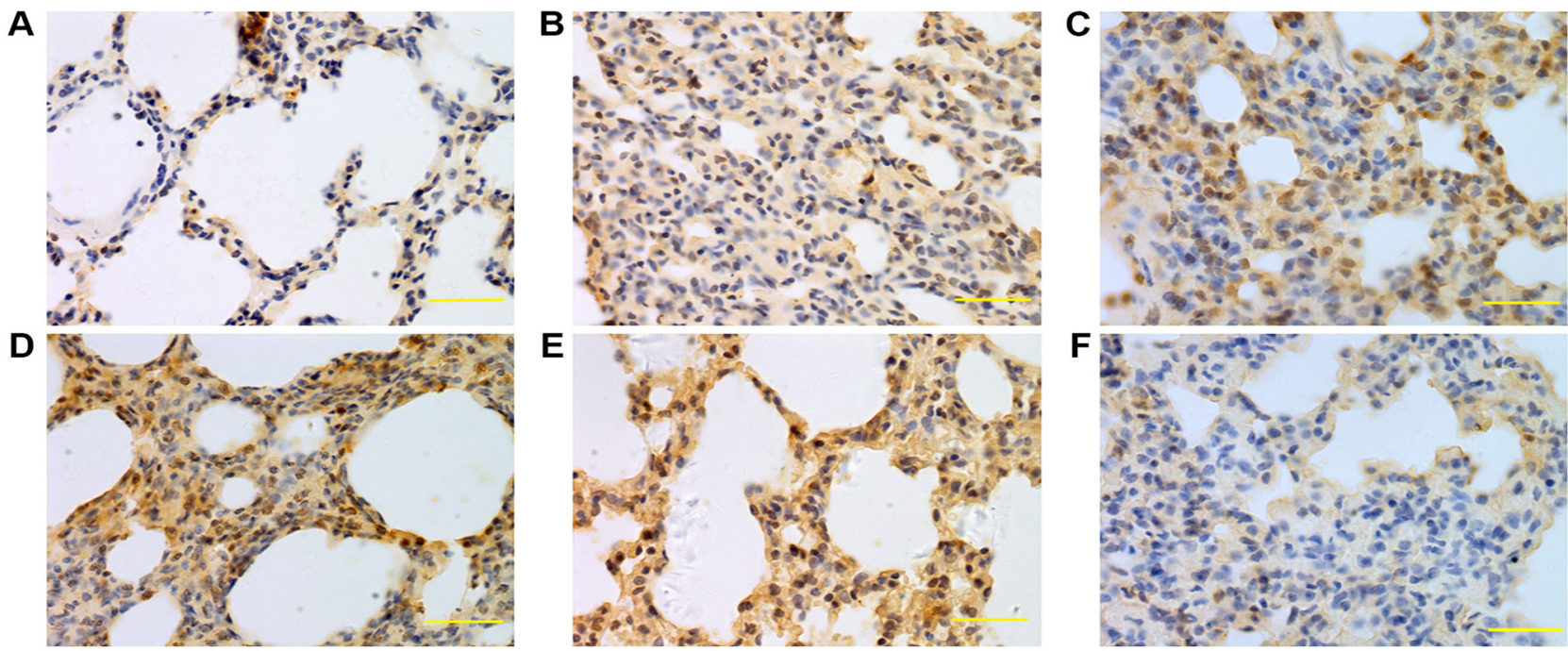

Figure 8. Expression of caspase-3 in lung tissue at $48 \mathrm{~h}$. Caspase-3 was mainly expressed in bronchial epithelial cells, alveolar epithelial cells and vascular and airway smooth muscle cells. The caspase-3 expression levels in the saline, low-, middle- and high-dose groups were higher compared with the normal group. (A) Control group, (B) saline group, (C) low-dose group, (D) middle-dose group, (E) high-dose group and (F) PBS group. Scale bars, $100 \mu \mathrm{m}$; magnification, x400; DAB staining. DAB, 3,3-diaminobenzidine.

NO has become the focus of studies investigating the mechanism underlying the gradual induction of lung tissue damage in smoke inhalation injury $(33,34)$. Endogenous NO is a transduction molecule involved in the intracellular signaling pathway and NO also affects arterial dilatation, decreases platelet viscosity and acts as an anti-inflammatory agent (35). According to previous studies, NO regulates apoptosis and inhibits the activities of several caspases $(36,37)$. The overproduction of $\mathrm{NO}$ mediates mitochondrial dysfunction and triggers apoptosis and, as more in-depth studies are being performed, the role of NO in the progression of smoke inhalation-induced lung injury is gradually attracting more attention (38).

A previous study demonstrated that $\mathrm{NO}$ is produced by three types of NOS: Endothelial NOS, iNOS and neuronal
NOS (39). During smoke inhalation injury, large quantities of active iNOS catalyze the decomposition of arginine to produce an excessive amount of NO (40). Simultaneously, excess NO binds to $\mathrm{O}^{-}$to form a strong oxidant $\left(\mathrm{ONOO}^{-}\right)$that mediates the production of a large amount of ROS, resulting in destruction of the cytomembrane and DNA, inducing cell lysis and necrosis (41). $\mathrm{ONOO}^{-}$acts mainly through two pathways: i) It affects pulmonary vascular permeability and the diffusion function of lung tissue, ii) it destroys the cytomembrane and DNA and iii) affects the energy metabolism of cells through negative feedback, leading to cell lysis and necrosis (42). One subtype of histone deacetylase, sirtuin 1 (SIRT1) serves an important role in maintaining gene stability, inhibiting apoptosis, inhibiting oxidative stress and exerting anti-inflammatory 

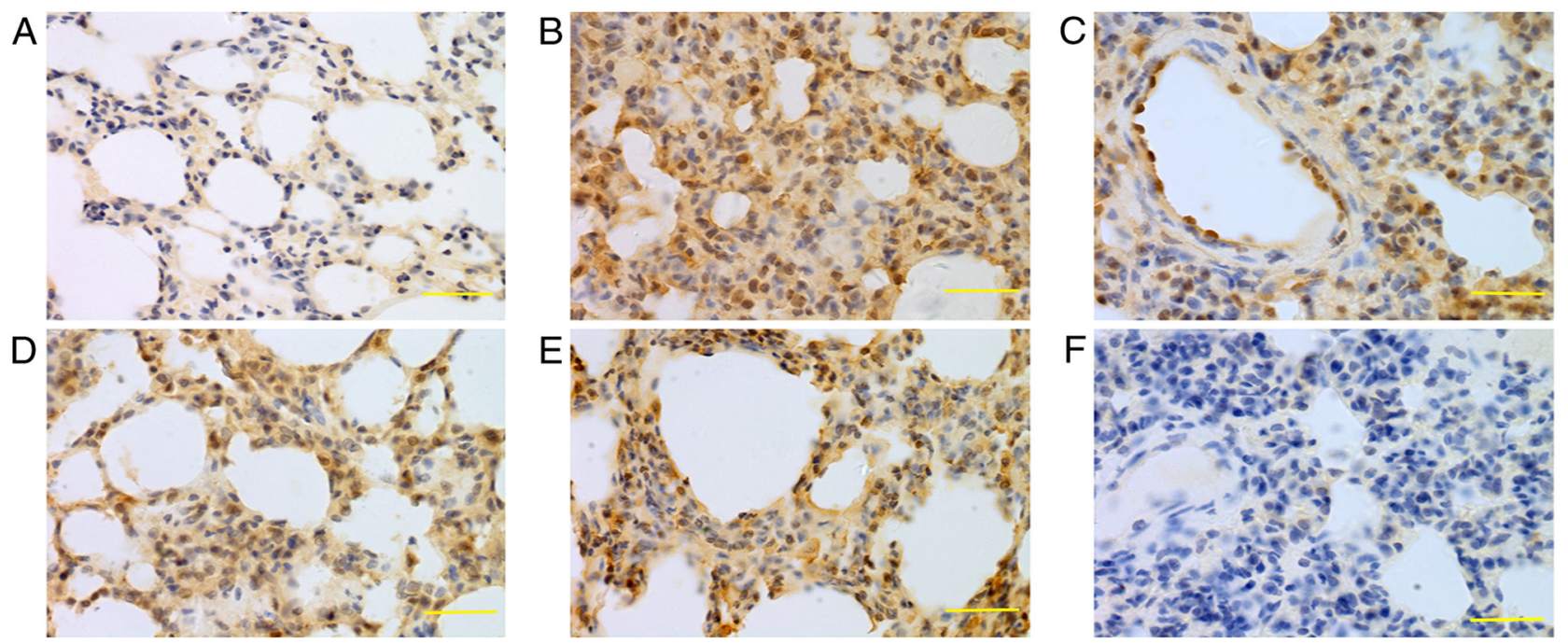

Figure 9. Expression of caspase-3 in lung tissue at $72 \mathrm{~h}$. Caspase-3 was mainly expressed in bronchial epithelial cells, alveolar epithelial cells and vascular and airway smooth muscle cells. The caspase-3 expression levels in the saline, low-, middle- and high-dose groups were higher compared with the normal group (A) Control group, (B) saline group, (C) low-dose group, (D) middle-dose group, (E) high-dose group and (F) PBS group. Scale bars, $100 \mu \mathrm{m}$; magnification, x400; DAB staining. DAB, 3,3-diaminobenzidine.
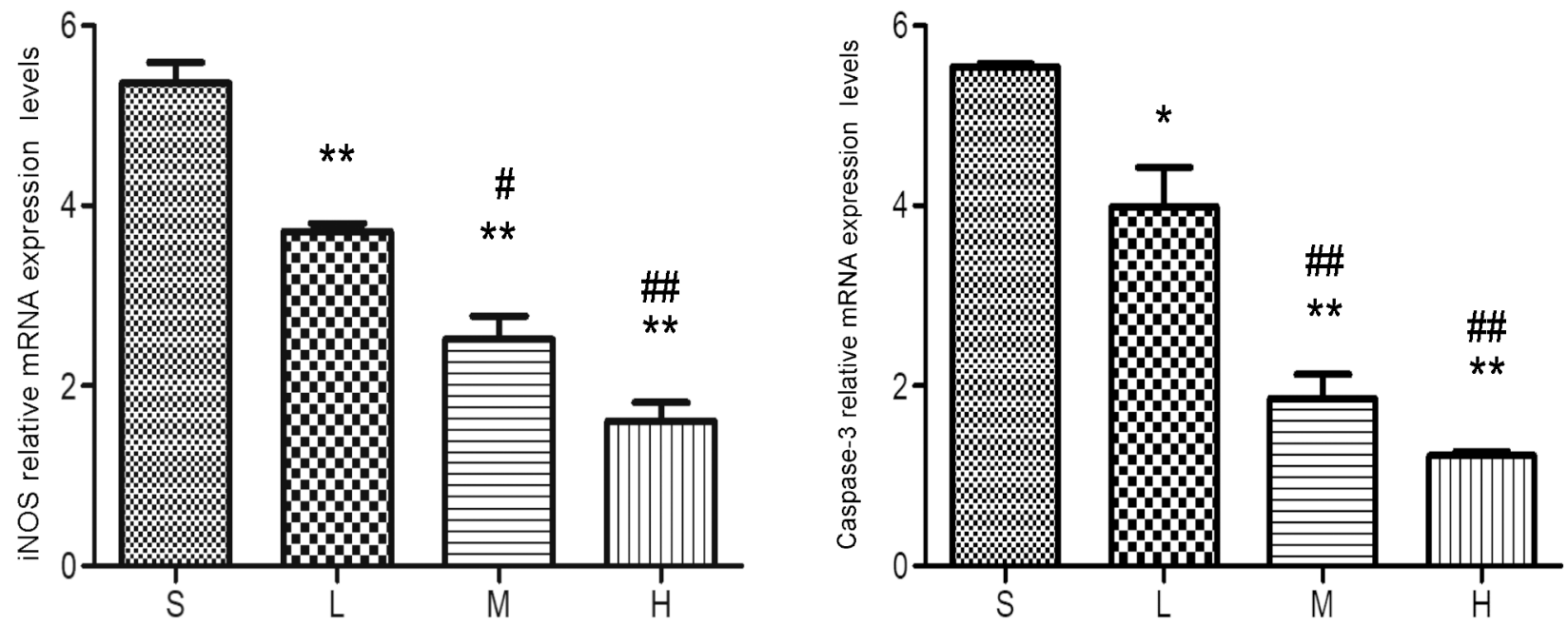

Figure 10. Relative mRNA expression levels of iNOS and caspase-3 at $24 \mathrm{~h}$. The levels of the iNOS and caspase-3 mRNA were lower in the low-, middle- and high-dose groups compared with the saline group. ${ }^{*} \mathrm{P}<0.05,{ }^{* *} \mathrm{P}<0.01$ vs. saline group; ${ }^{\#} \mathrm{P}<0.05,{ }^{\# \#} \mathrm{P}<0.01$ vs. low-dose group. iNOS, inducible nitric oxide synthase; S, saline group; L, low-dose group; M, middle-dose group; H, high-dose group.

effects (43). However, excessive production of NO can inhibit SIRT1, thereby inhibiting P53 pathway-dependent apoptosis through a deacetylation pathway and ultimately promoting apoptosis (44).

However, $\mathrm{NO}$ also activates protein kinase $\mathrm{G}(\mathrm{PKG})$, through the NO/cyclic guanosine monophosphate/PKG pathway (45). Additionally, phosphorylated p38 mitogen-activated protein kinase activates caspase-3 (46). Caspase-3, which serves as an intersection of the endogenous and exogenous apoptotic pathways, is the main protein with apoptotic activity (47). Therefore, its expression levels can directly reflect the occurrence of apoptosis (48). Associated inflammatory mediators and cells regulated by NF- $\kappa \mathrm{B}$ can further promote the activation of NF- $\mathrm{BB}$, TNF- $\alpha$, IL-6 and iNOS, among other factors, indicating that NF- $\mathrm{KB}$ serves a key role in smoke inhalation injury (49). Pro-inflammatory cytokines, such as IL-1 and TNF- $\alpha$, induce the expression of iNOS and consequently the generation of large quantities of NO, resulting in cell degeneration and apoptosis (50).

Toll-like receptor 4 (TLR4), one of the most important proteins involved in cellular signaling, activates the downstream nuclear factor NF- $\mathrm{KB}$ when bound to its ligand (51). Combined with the present results, it can be hypothesized that simvastatin decreases the expression of iNOS and caspase- 3 by inhibiting the activation of NF- $\mathrm{KB}$, which in turn is mediated by suppressing TLR4 expression on the surfaces of CD14+ monocytes in peripheral blood and attenuating downstream signal pathways. This protects the lungs against cytotoxicity caused by NF- $\mathrm{KB}$ and NO overproduction, and decreasing cell damage and apoptosis (52). At the same time, overproduction 
Table I. Activity of superoxide dismutase in lung tissue (U/mg prot) and serum (U/ml) at different time points and different doses of simvastatin.

\begin{tabular}{|c|c|c|c|c|c|c|}
\hline \multirow[b]{2}{*}{ Groups } & \multicolumn{2}{|c|}{$24 \mathrm{~h}$} & \multicolumn{2}{|c|}{$48 \mathrm{~h}$} & \multicolumn{2}{|c|}{$72 \mathrm{~h}$} \\
\hline & Serum & Lung & Serum & Lung & Serum & Lung \\
\hline Control group & $59.92 \pm 8.13$ & $250.8 \pm 11.27$ & $57.83 \pm 6.67$ & $244.25 \pm 11.58$ & $60.31 \pm 2.29$ & $248.03 \pm 3.67$ \\
\hline Saline group & $16.32 \pm 1.67^{\mathrm{a}}$ & $161.45 \pm 10.51^{\mathrm{a}}$ & $16.45 \pm 1.30^{\mathrm{a}}$ & $164.95 \pm 14.97^{\mathrm{a}}$ & $19.96 \pm 1.53^{\mathrm{a}}$ & $157.79 \pm 4.97^{\mathrm{a}}$ \\
\hline Low-dose group & $23.81 \pm 3.53^{\mathrm{a}, \mathrm{b}}$ & $183.77 \pm 9.22^{\mathrm{a}, \mathrm{b}}$ & $28.26 \pm 3.09^{\mathrm{a}, \mathrm{b}}$ & $189.14 \pm 10.01^{\mathrm{a}, \mathrm{b}}$ & $27.78 \pm 2.03^{\mathrm{a}, \mathrm{b}}$ & $197.65 \pm 7.57^{\mathrm{a}, \mathrm{b}}$ \\
\hline Middle-dose group & $39.57 \pm 6.34^{\mathrm{a}-\mathrm{c}}$ & $215.03 \pm 9.19^{\mathrm{a}-\mathrm{c}}$ & $43.76 \pm 5.56^{\mathrm{a}-\mathrm{c}}$ & $220.41 \pm 6.05^{\mathrm{a}-\mathrm{c}}$ & $38.73 \pm 3.08^{\mathrm{a}-\mathrm{c}}$ & $213.84 \pm 6.93^{\mathrm{a}-\mathrm{c}}$ \\
\hline High-dose group & $39.77 \pm 4.90^{\mathrm{a}-\mathrm{c}}$ & $226.97 \pm 7.37^{\mathrm{a}-\mathrm{d}}$ & $43.04 \pm 5.10^{\mathrm{a}-\mathrm{c}}$ & $224.99 \pm 1.85^{\mathrm{a}-\mathrm{c}}$ & $39.86 \pm 4.60^{\mathrm{a}-\mathrm{c}}$ & $227.52 \pm 10.05^{\mathrm{a}-\mathrm{d}}$ \\
\hline
\end{tabular}

All the values are expressed as the mean \pm standard deviation. ${ }^{\mathrm{a}} \mathrm{P}<0.05$ vs. control group, ${ }^{\mathrm{b}} \mathrm{P}<0.05$ vs. saline group, ${ }^{\mathrm{c}} \mathrm{P}<0.05 \mathrm{vs}$. low-dose group and ${ }^{\mathrm{d}} \mathrm{P}<0.05$, vs. middle-dose group.
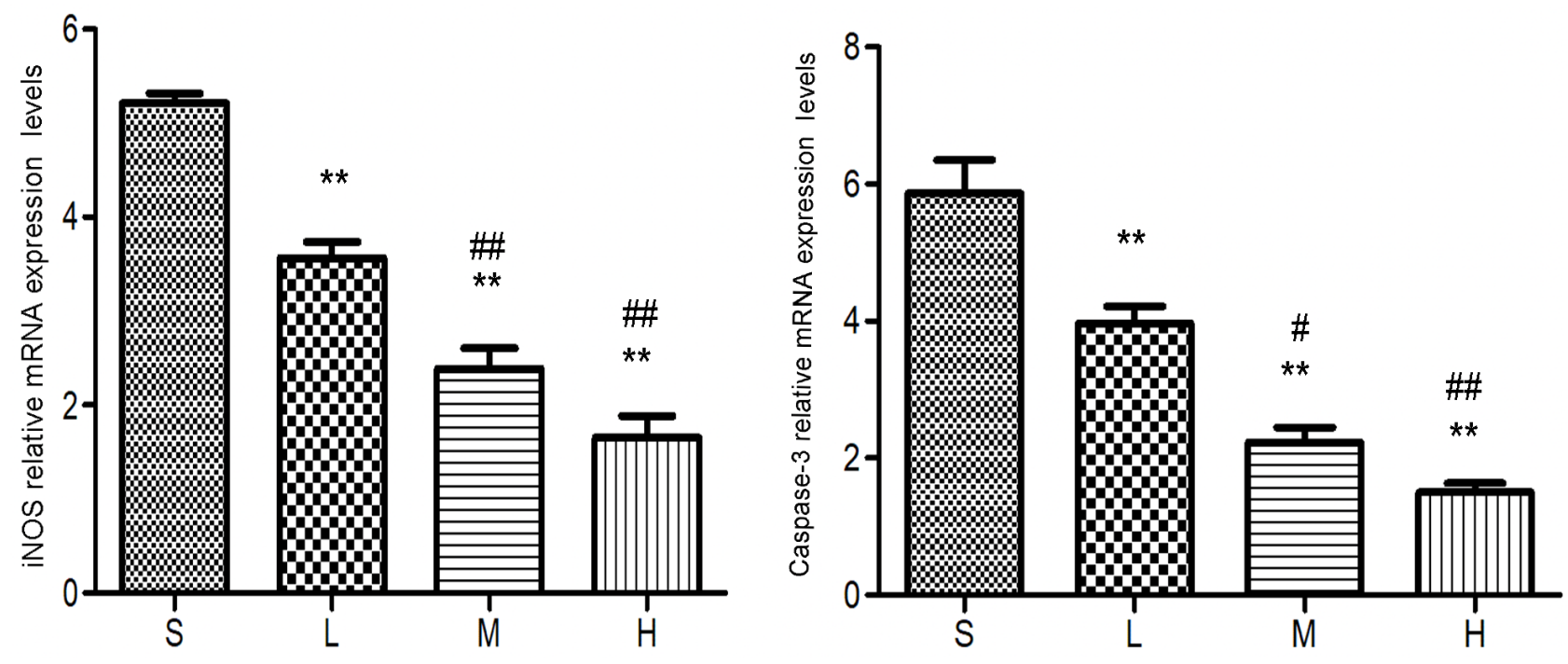

Figure 11. Relative mRNA expression levels of iNOS and caspase-3 at $48 \mathrm{~h}$. The levels of the iNOS and caspase-3 mRNA were lower in the low-, middle- and high-dose groups compared with the saline group. ${ }^{* *} \mathrm{P}<0.01$ vs. saline group; ${ }^{\#} \mathrm{P}<0.05,{ }^{\# \#} \mathrm{P}<0.01$ vs. low-dose group. iNOS, inducible nitric oxide synthase; $\mathrm{S}$, saline group; L, low-dose group; M, middle-dose group; H, high-dose group.
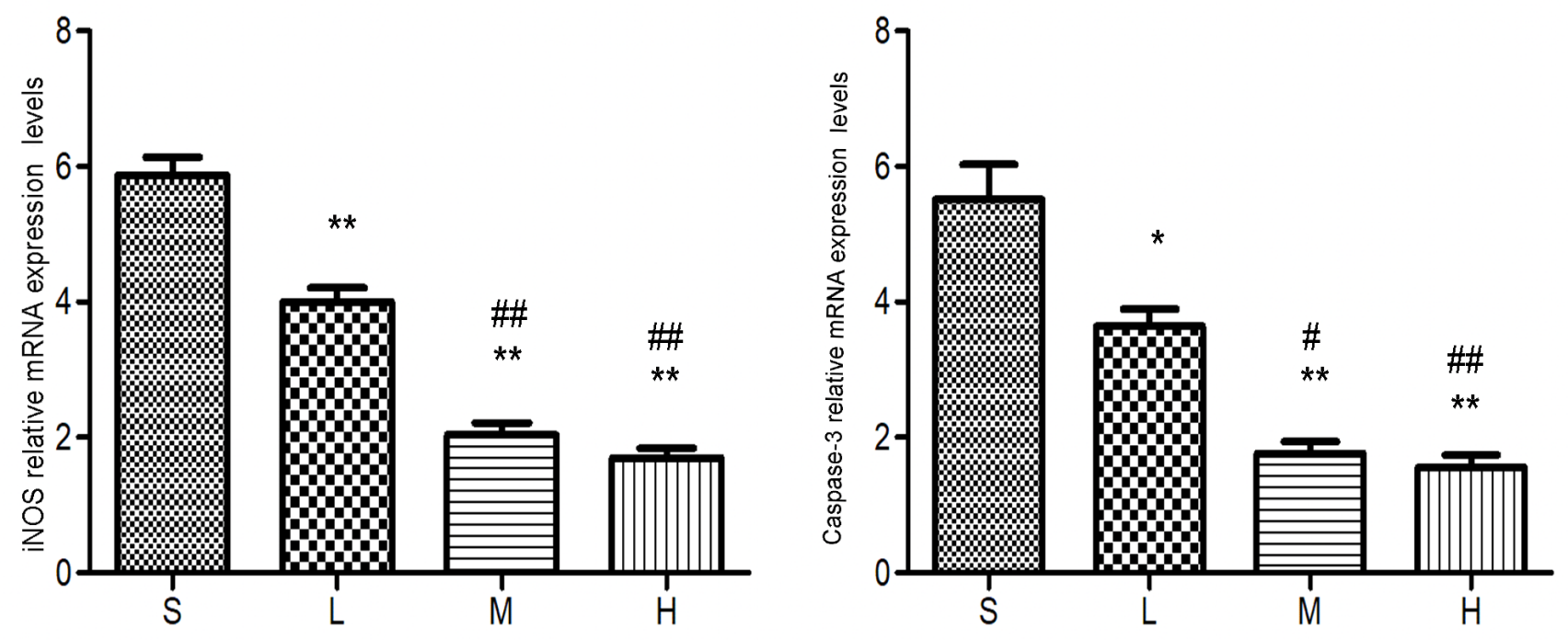

Figure 12. Relative mRNA expression levels of iNOS and caspase- 3 at $72 \mathrm{~h}$. The levels of the iNOS and caspase- 3 mRNA were lower in the low-, middle- and high-dose groups compared with the saline group. ${ }^{~} \mathrm{P}<0.05,{ }^{* *} \mathrm{P}<0.01$ vs. saline group; ${ }^{~} \mathrm{P}<0.05,{ }^{\# \#} \mathrm{P}<0.01$ vs. low-dose group. iNOS, inducible nitric oxide synthase; S, saline group; L, low-dose group; M, middle-dose group; H, high-dose group. 
Table II. Malondialdehyde in lung tissue (nmol/mg prot) and serum $(\mathrm{nmol} / \mathrm{ml})$ at different time points and different doses of simvastatin.

$24 \mathrm{~h}$

$48 \mathrm{~h}$

$72 \mathrm{~h}$

\begin{tabular}{|c|c|c|c|c|c|c|}
\hline Groups & Serum & Lung & Serum & Lung & Serum & Lung \\
\hline Control & $4.43 \pm 0.65$ & $3.59 \pm 0.33$ & $4.28 \pm 0.47$ & $3.33 \pm 0.27$ & $4.58 \pm 0.43$ & $3.88 \pm 0.13$ \\
\hline Saline & $11.11 \pm 2.14^{\mathrm{a}}$ & $9.68 \pm 0.89^{\mathrm{a}}$ & $10.11 \pm 0.60^{\mathrm{a}}$ & $10.33 \pm 0.87^{\mathrm{a}}$ & $9.95 \pm 0.62^{\mathrm{a}}$ & $10.28 \pm 0.38^{\mathrm{a}}$ \\
\hline Low-dose & $8.95 \pm 0.65^{\mathrm{a}, \mathrm{b}}$ & $7.43 \pm 0.86^{\mathrm{a}, \mathrm{b}}$ & $8.59 \pm 0.57^{\mathrm{a}, \mathrm{b}}$ & $7.68 \pm 1.11^{\mathrm{a}, \mathrm{b}}$ & $8.37 \pm 0.20^{\mathrm{a}, \mathrm{b}}$ & $8.51 \pm 0.71^{\mathrm{a}, \mathrm{b}}$ \\
\hline Middle-dose & $7.64 \pm 0.34^{\mathrm{a}-\mathrm{c}}$ & $5.57 \pm 0.68^{\mathrm{a}-\mathrm{c}}$ & $7.22 \pm 0.38^{\mathrm{a}-\mathrm{c}}$ & $5.68 \pm 0.84^{\mathrm{a}-\mathrm{c}}$ & $6.66 \pm 0.59^{\mathrm{a}-\mathrm{c}}$ & $4.92 \pm 0.34^{\mathrm{a}-\mathrm{c}}$ \\
\hline High-dose & $6.65 \pm 0.37^{\mathrm{a}-\mathrm{c}}$ & $5.19 \pm 0.37^{\mathrm{a}-\mathrm{c}}$ & $6.08 \pm 0.68^{\mathrm{a}-\mathrm{d}}$ & $5.24 \pm 0.29^{\mathrm{a}-\mathrm{c}}$ & $6.08 \pm 0.66^{\mathrm{a}-\mathrm{c}}$ & $4.99 \pm 0.26^{\mathrm{a}-\mathrm{c}}$ \\
\hline
\end{tabular}

All the values are expressed as the mean \pm standard deviation. ${ }^{\mathrm{a}} \mathrm{P}<0.05$, vs. control group, ${ }^{\mathrm{b}} \mathrm{P}<0.05$, vs. saline group, ${ }^{\mathrm{c}} \mathrm{P}<0.05$. vs. low-dose group, ${ }^{\mathrm{d}} \mathrm{P}<0.05$, vs. middle-dose group.
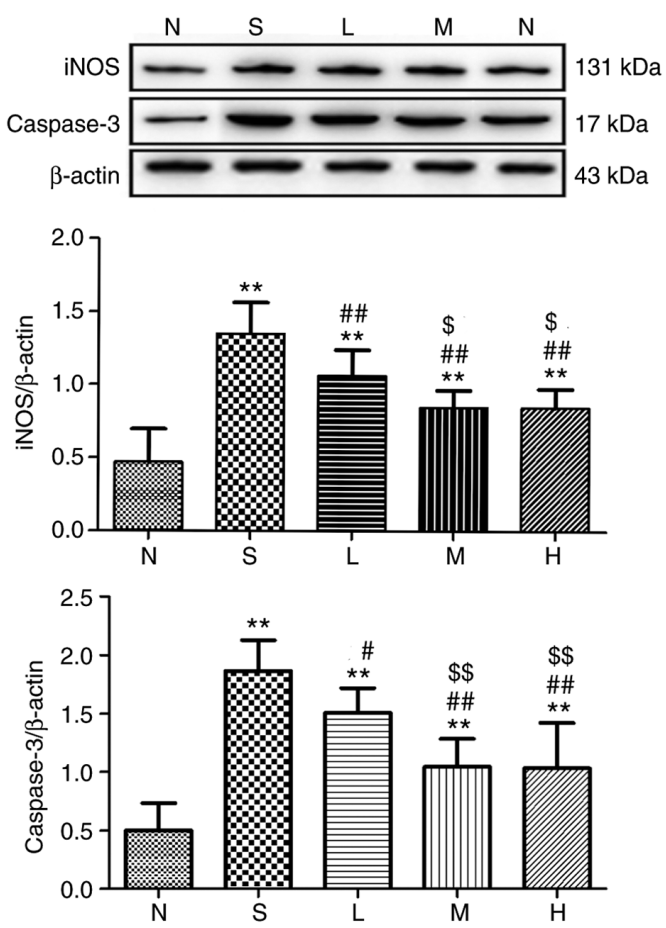

Figure 13. Relative expression of iNOS and caspase-3 in lung tissue at $24 \mathrm{~h}$ The levels of iNOS and caspase- 3 proteins in rat lungs were detected and immunoreactive bands were observed at 131 and $17 \mathrm{kDa}$, respectively. The levels of the iNOS and caspase-3 proteins were higher in the saline, low-, middle- and high-dose groups compared with the control group. ${ }^{* *} \mathrm{P}<0.01$ vs. control group; ${ }^{\#} \mathrm{P}<0.05,{ }^{\# \#} \mathrm{P}<0.01$ vs. saline group; ${ }^{\$} \mathrm{P}<0.05,{ }^{\$ \$} \mathrm{P}<0.01$ vs. low-dose group. iNOS, inducible nitric oxide synthase; $\mathrm{N}$, control group $\mathrm{S}$, saline group; L, low-dose group; M, middle-dose group; H, high-dose group.

of NO can block the high levels of $\mathrm{Ca}^{2+}$ induced by ROS and inhibit apoptosis through the Bcl-2 signaling pathway (53).

The levels of MDA, a product of the destruction of polyunsaturated fatty acids in the cell membrane, indirectly reflects the grade of oxidative damage. SOD acts as an important antioxidant enzyme by antagonizing and blocking oxygen free radicals to decrease cell damage and thus speeding the repair of free radical-induced damage in cells $(54,55)$. High levels of oxygen free radicals exceed the capacity of the antioxidant system during smoke inhalation injury, which
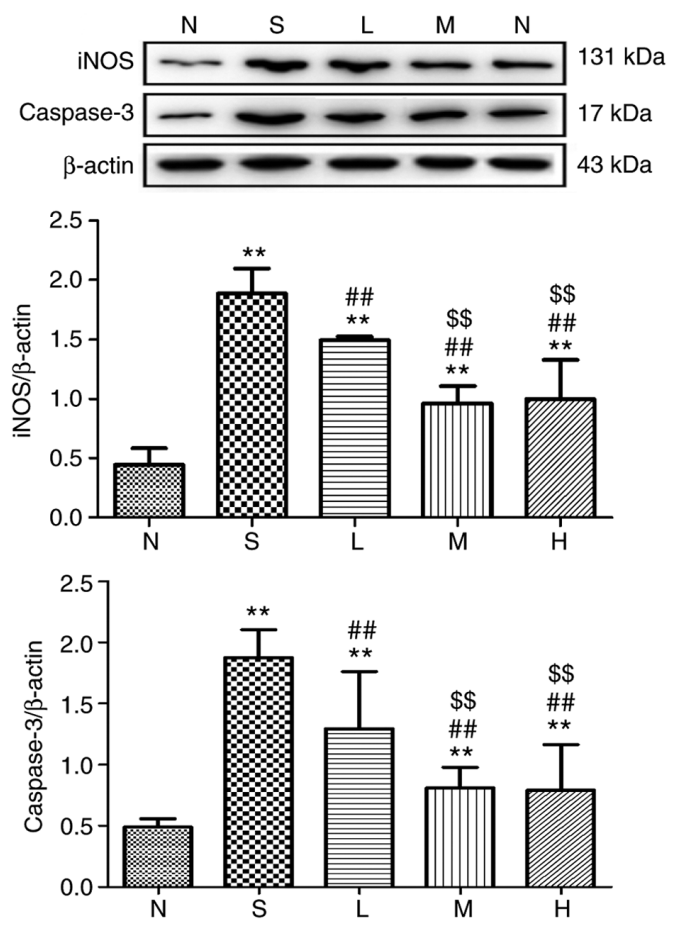

Figure 14. Relative expression of iNOS and caspase-3 in lung tissue at $48 \mathrm{~h}$ The levels of iNOS and caspase-3 proteins in rat lungs were detected and immunoreactive bands were observed at $\sim 131$ and $17 \mathrm{kDa}$, respectively. The levels of the iNOS and caspase-3 proteins were higher in the saline, low-, middle- and high-dose groups compared with the control group. ${ }^{* *} \mathrm{P}<0.01$ vs. control group; ${ }^{\# \#} \mathrm{P}<0.01$ vs. saline group; ${ }^{\$ \$} \mathrm{P}<0.01$ vs. low-dose group. iNOS, inducible nitric oxide synthase; $\mathrm{N}$, control group $\mathrm{S}$, saline group; L, low-dose group; $\mathrm{M}$, middle-dose group; $\mathrm{H}$, high-dose group.

causes lipid peroxidation and subsequent destruction of cell membranes (56). Simvastatin decreases the activation of neutrophils and arachidonic acid metabolism following inhalation injury, leading to a decrease in the production of oxygen free radicals and a consequential consumption of antioxidant substances. In turn, this increases SOD production and inhibits oxidative stress in response to smoke inhalation injury, thus reducing cell damage $(57,58)$.

In the present study, iNOS and caspase-3 expression levels were significantly increased following smoke inhalation lung 

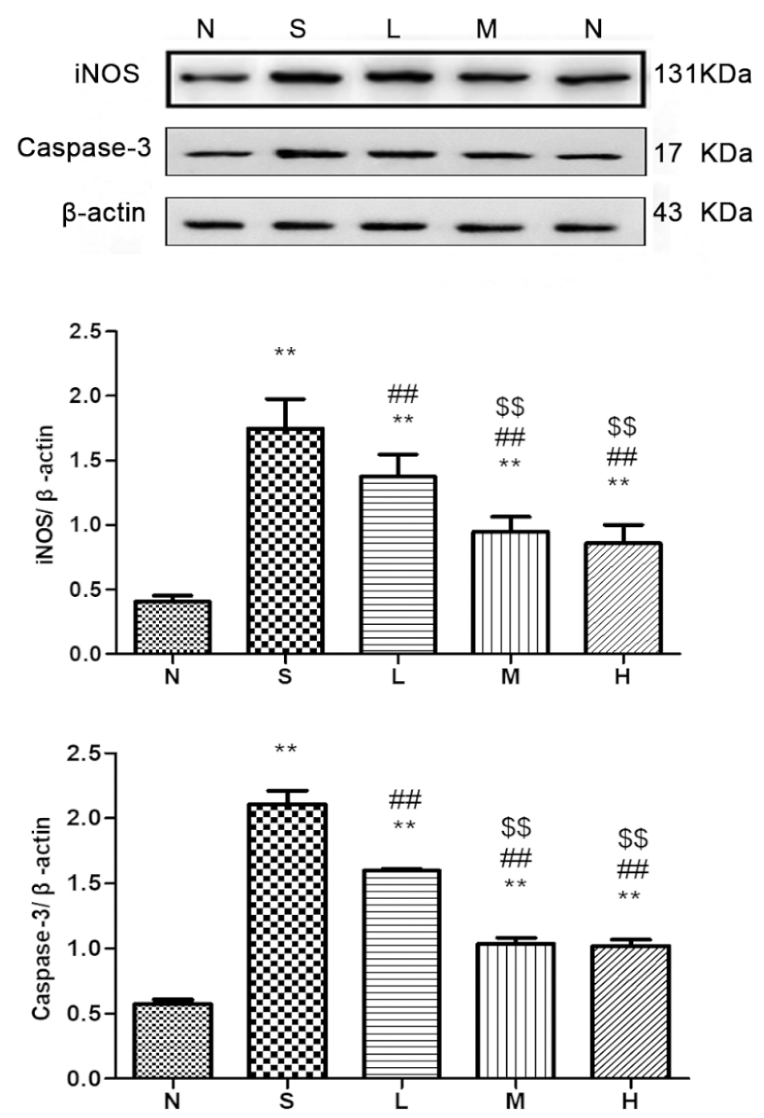

Figure 15. Relative expression of iNOS and caspase-3 in lung tissue at $72 \mathrm{~h}$. The levels of iNOS and caspase- 3 proteins in rat lungs were detected and immunoreactive bands were observed at $\sim 131$ and $17 \mathrm{kDa}$, respectively. The levels of the iNOS and caspase-3 proteins were higher in the saline, lowmiddle- and high-dose groups compared with the control group. ${ }^{* *} \mathrm{P}<0.01$ vs. control group; ${ }^{\# \#} \mathrm{P}<0.01$ vs. saline group; ${ }^{\$} \mathrm{P}<0.01$ vs. low-dose group. iNOS, inducible nitric oxide synthase; $\mathrm{N}$, control group $\mathrm{S}$, saline group; L, low-dose group; $\mathrm{M}$, middle-dose group; $\mathrm{H}$, high-dose group.

injury $(\mathrm{P}<0.05)$, indicating that lung tissue injury was aggravated, whereas iNOS and caspase-3 expression levels in the low-, middle- and high-dose groups were significantly lower compared with the saline group $(\mathrm{P}<0.05)$. As an important antioxidant enzyme in vivo, SOD activity was significantly decreased following smoke inhalation lung injury $(\mathrm{P}<0.05)$ and MDA content was significantly increased $(\mathrm{P}<0.05)$, at 24 , 48 and $72 \mathrm{~h}$. In addition, simvastatin treatment increased SOD activity and decreased the MDA content, and this effect was dose-dependent within $0-50 \mathrm{mg} / \mathrm{kg}$. Therefore, simvastatin could inhibit the formation of iNOS and inhibit apoptosis and lung tissue damage following smoke inhalation, thus exerting a certain protective effect on lung tissue with smoke inhalation injury. Although the therapeutic effect of simvastatin on inhalation injury has been widely recognized (59), the specific underlying molecular mechanisms and appropriate dosages remain unclear.

In the present study, simvastatin inhibited iNOS and caspase-3 expression and decreased NO synthesis and lung cell apoptosis. In contrast, simvastatin exerted some antioxidant effects and inhibited excessive oxidative stress in rats with smoke inhalation injury, thus exerting a protective effect against smoke inhalation injury.

\section{Acknowledgements}

The authors thank Ms Xiu-hua Ren from the School of Basic Medicine of Zhengzhou University for her help with the pathological detection and immunohistochemistry experiments.

\section{Funding}

The present study was supported by grants from the National Natural Science Cooperation Foundation of China (grant no. U1604188) and the 2015 Key Scientific and Technological Projects of Henan Province (grant no. 152102410065).

\section{Availability of data and materials}

The datasets used and/or analyzed during the current study are available from the corresponding author on reasonable request.

\section{Authors' contributions}

The authors all contributed to the research. ZJC, ZM, CC, PFG and QNM conceived and designed the study. RQY, YG and IK performed the experiments. RQY and XBW wrote the paper and performed analysis or interpretation of data. ZJC reviewed and edited the manuscript for important intellectual content, and final approval of the version to be published. All authors read and approved the final manuscript.

\section{Ethics approval and consent to participate}

The present study was approved by the Animal Care and Use Committee of Zhengzhou University (Henan, China) and conducted in accordance with the National Institutes of Health Guide for the Care and Use of Laboratory Animals.

\section{Patient consent for publication}

Not applicable.

\section{Competing interests}

The authors declare that they have no competing interests.

\section{References}

1. Ballard-Croft C, Sumpter LR, Broaddus R, Alexander J, Wang D and Zwischenberger JB: Ovine smoke/burn ARDS model: A new ventilator-controlled smoke delivery system. J Surg Res 164: e155-e162, 2010

2. De Carvalho FO, Silva ÉR, Felipe FA, Teixeira LGB, Zago LBS, Nunes PS, Shanmugam S, Serafini MR and Araújo AAS: Natural and synthetic products used for the treatment of smoke inhalation: A patent review. Expert Opin Ther Pat 27: 877-886, 2017.

3. Tanizaki S: Assessing inhalation injury in the emergency room. Open Access Emerg Med 7: 31-37, 2015.

4. Lee AS and Mellins RB: Lung injury from smoke inhalation. Paediatr Respir Rev 7: 123-128, 2006.

5. Matthay MA and Zemans RL: The acute respiratory distress syndrome: Pathogenesis and treatment. Annu Rev Pathol 6: 147-163, 2011.

6. Barsanti KC, Luo W, Isabelle LM, Pankow JF and Peyton DH: Tobacco smoke particulate matter chemistry by NMR. Magn Reson Chem 45: 167-170, 2007.

7. Wu ZY, Li H and Tang YJ: Effect of simvastatin on the SIRT2/NF- $\kappa$ B pathway in rats with acute pulmonary embolism. Pharm Biol 56: 511-518, 2018. 
8. Cox RA, Jacob S, Oliveras G, Murakami K, Enkhbaatar P, Traber L, Schmalstieg FC, Herndon DN, Traber DL and Hawkins HK: Pulmonary expression of nitric oxide synthase isoforms in sheep with smoke inhalation and burn injury. Exp Lung Res 35: 104-118, 2009.

9. Liu X, Ai F, Li H, Xu Q, Mei L, Miao J, Wen Q, Zhang C, Zhang S, Zhou J, et al: Anti-inflammatory effects of shenfu injection against acute lung injury through inhibiting HMGB1-NF- $\kappa \mathrm{B}$ pathway in a rat model of endotoxin shock. Evid Based Complement Alternat Med 2019: 9857683, 2019.

10. Hosogi S, Iwasaki Y, Yamada T, Komatani-Tamiya N, Hiramatsu A, Kohno Y, Ueda M, Arimoto T and Marunaka Y: Effect of inducible nitric oxide synthase on apoptosis in Candida-induced acute lung injury. Biomed Res 29: 257-266, 2008.

11. Ray PD, Huang BW and Tsuji Y: Reactive oxygen species (ROS) homeostasis and redox regulation in cellular signaling. Cell Signal 24: 981-990, 2012.

12. Liu S, Yue Y, Pan P, Zhang L, Su X, Li H, Li H, Li Y, Dai M, Li Q and Mao Z: IRF-1 intervention in the classical ROS-dependent release of NETs during LPS-induced acute lung injury in mice. Inflammation 42: 387-403, 2019.

13. Montaño M, Cisneros J, Ramírez-Venegas A, Pedraza-Chaverri J, Mercado D, Ramos C and Sansores RH: Malondialdehyde and superoxide dismutase correlate with FEV(1) in patients with COPD associated with wood smoke exposure and tobacco smoking. Inhal Toxicol 22: 868-874, 2010.

14. Karmali KN, Lloyd-Jones DM, Berendsen MA, Goff DC Jr, Sanghavi DM, Brown NC, Korenovska L and Huffman MD: Drugs for primary prevention of atherosclerotic cardiovascular disease: An overview of systematic reviews. JAMA Cardiol 1: 341-349, 2016.

15. Yan YL, Qiu B, Hu LJ, Jing XD, Liu YJ, Deng SB, Du JL and She Q: Efficacy and safety evaluation of intensive statin therapy in older patients with coronary heart disease: A systematic review and meta-analysis. Eur J Clin Pharmacol 69: 2001-2009, 2013.

16. Wang L, Mehta S, Gillis C, Law C and Taneja R: Modulation of neutrophil apoptosis by murine pulmonary microvascular endothelial cell inducible nitric oxide synthase. Biochem Biophys Res Commun 401: 207-212, 2010.

17. Aoki T, Kataoka H, Ishibashi R, Nozaki K and Hashimoto N: Simvastatin suppresses the progression of experimentally induced cerebral aneurysms in rats. Stroke 39: 1276-1285, 2008.

18. Esposito E, Rinaldi B, Mazzon E, Donniacuo M, Impellizzeri D, Paterniti I, Capuano A, Bramanti $P$ and Cuzzocrea $S$ : Anti-inflammatory effect of simvastatin in an experimental model of spinal cord trauma: Involvement of PPAR-alpha J Neuroinflammation 9: 81, 2012.

19. Shyamsundar M, McKeown ST, O'Kane CM, Craig TR, Brown V, Thickett DR, Matthay MA, Taggart CC, Backman JT, Elborn JS and McAuley DF: Simvastatin decreases lipopolysaccharide-induced pulmonary inflammation in healthy volunteers Am J Respir Crit Care Med 179: 1107-1114, 2009.

20. National Research Council Committee for the Update of the Guide for the Care and Use of Laboratory Animals: The National Academies Collection: Reports funded by National Institutes of Health. In: Guide for the Care and Use of Laboratory Animals National Academies Press (US) Copyright (C) 2011, National Academy of Sciences, Washington (DC), 2011.

21. Liu PY, Liu YW, Lin LJ, Chen JH and Liao JK: Evidence for statin pleiotropy in humans: Differential effects of statins and ezetimibe on rho-associated coiled-coil containing protein kinase activity, endothelial function and inflammation. Circulation 119: 131-138, 2009.

22. Zhu F, Qiu X, Wang J, Jin Y, Sun Y, Lv T and Xia Z: A rat model of smoke inhalation injury. Inhal Toxicol 24: 356-364, 2012.

23. Garip S and Severcan F: Determination of simvastatin-induced changes in bone composition and structure by Fourier transform infrared spectroscopy in rat animal model. J Pharm Biomed Anal 52: 580-588, 2010

24. Livak KJ and Schmittgen TD: Analysis of relative gene expression data using real-time quantitative PCR and the 2(-Delta Delta C(T)) method. Methods 25: 402-408, 2001

25. de Carvalho FO, Felipe FA, de Melo Costa AC, Teixeira LG, Silva ÉR, Nunes PS, Shanmugam S, de Lucca Junior W, Quintans JS and de Souza Araújo AA: Inflammatory mediators and oxidative stress in animals subjected to smoke inhalation: A systematic review. Lung 194: 487-499, 2016.
26. Lange M, Szabo C, Traber DL, Horvath E, Hamahata A, Nakano Y, Traber LD, Cox RA, Schmalstieg FC, Herndon DN and Enkhbaatar P: Time profile of oxidative stress and neutrophil activation in ovine acute lung injury and sepsis. Shock 37 : 468-472, 2012.

27. Tan W, Xue-bin C, Tian Z, Xiao-wu C, Pei-pei H, Zhi-bin C and Bei-sha T: Effects of simvastatin on the expression of inducible nitric oxide synthase and brain-derived neurotrophic factor in a lipopolysaccharide-induced rat model of Parkinson disease. Int J Neurosci 126: 278-286, 2016

28. Lee HJ, Shin JS, Lee WS, Shim HY, Park JM, Jang DS and Lee KT: Chikusetsusaponin IVa methyl ester isolated from the roots of achyranthes japonica suppresses LPS-induced iNOS, TNF- $\alpha$, IL-6, and IL-1 $\beta$ expression by NF- $\kappa$ B and AP-1 inactivation. Biol Pharm Bull 39: 657-664, 2016.

29. Matsumoto J, Dohgu S, Takata F, Machida T, Bölükbaşi Hatip FF, Hatip-Al-Khatib I, Yamauchi A and Kataoka Y: TNF- $\alpha$-sensitive brain pericytes activate microglia by releasing IL- 6 through

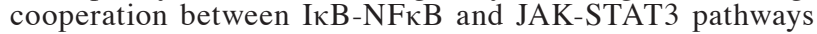
Brain Res 1692: 34-44, 2018

30. Sun JL, Gao Y, Cui ZJ and Guo PF: The anti-inflammatory effects of simvastatin in a rat model of smoke inhalation lung injury. Int J Clin Exp Med 12: 12740-12746, 2019.

31. Refaie MMM, El-Hussieny M and Zenhom NM: Protective role of nebivolol in cadmium-induced hepatotoxicity via downregulation of oxidative stress, apoptosis and inflammatory pathways. Environ Toxicol Pharmacol 58: 212-219, 2018.

32. Wang X, Luo B, Lu Y, Pang D, Zheng J, Mo J, Huang H and Feng J: The triggering receptor expressed by myeloid cells-1 activates TLR4-MyD88-NF- $\mathrm{B}$-dependent signaling to aggravate ventilation-induced lung inflammation and injury in mice. Cell Tissue Res 374: 137-148, 2018.

33. Soejima K, Traber LD, Schmalstieg FC, Hawkins H, Jodoin JM, Szabo C, Szabo E, Virag L, Salzman A and Traber DL: Role of nitric oxide in vascular permeability after combined burns and smoke inhalation injury. Am J Respir Crit Care Med 163: 745-752, 2001.

34. Shun-Zhen Q and Hong-Hang Z: The effects of inhaled nitric oxide on the levels of cGMP plasma and lung tissue in a canine model of smoke inhalation injury. Burns 28: 299-304, 2002.

35. Lange M, Hamahata A, Enkhbaatar P, Cox RA, Nakano Y, Westphal M, Traber LD, Herndon D and Traber DL: Beneficial effects of concomitant neuronal and inducible nitric oxide synthase inhibition in ovine burn and inhalation injury. Shock 35 : 626-631, 2011.

36. Rössig L, Fichtlscherer B, Breitschopf K, Haendeler J, Zeiher AM, Mülsch A and Dimmeler S: Nitric oxide inhibits caspase-3 by S-nitrosation in vivo. J Biol Chem 274: 6823-6826, 1999.

37. Kim YM, Talanian RV and Billiar TR: Nitric oxide inhibits apoptosis by preventing increases in caspase-3-like activity via two distinct mechanisms. J Biol Chem 272: 31138-31148, 1997.

38. Bai S, Hu Z, Yang Y, Yin Y, Li W, Wu L and Fang M: Anti-inflammatory and neuroprotective effects of triptolide via the NF- $\kappa \mathrm{B}$ signaling pathway in a rat MCAO model. Anat Rec (Hoboken) 299: 256-266, 2016. 20. Enkhbaatar P, Wang J, Saunders F, Lange M, Hamahata A, Rehberg S, Parkinson JF, Traber LD, Herndon DN and Traber DL: Mechanistic aspects of inducible nitric oxide synthase-induced lung injury in burn trauma. Burns 37: 638-645, 2011

39. Li WC, Zou ZJ, Zhou MG, Chen L, Zhou L, Zheng YK and He ZJ: Effects of simvastatin on the expression of inducible NOS in acute lung injury in septic rats. Int J Clin Exp Pathol 8: 15106-15111, 2015.

40. Ahmed AM: Inhibition of inducible nitric oxide synthase (iNOS) by simvastatin attenuates cardiac hypertrophy in rats. Folia Morphol (Warsz) 76: 15-27, 2017.

41. Kim BC, Kim YS, Lee JW, Seo JH, Ji ES, Lee H, Park YI and Kim CJ: Protective effect of coriolus versicolor cultivated in citrus extract against nitric oxide-Induced apoptosis in human neuroblastoma SK-N-MC cells. Exp Neurobiol 20: 100-109, 2011.

42. Lange M, Szabo C, Enkhbaatar P, Connelly R, Horvath E, Hamahata A, Cox RA, Esechie A, Nakano Y, Traber LD, et al: Beneficial pulmonary effects of a metalloporphyrinic peroxynitrite decomposition catalyst in burn and smoke inhalation injury. Am J Physiol Lung Cell Mol Physiol 300: L167-L175, 2011.

43. Liu X, Jin X, Yu D and Liu G: Suppression of NLRP3 and NF- $\kappa B$ signaling pathways by $\alpha$-Cyperone via activating SIRT1 contributes to attenuation of LPS-induced acute lung injury in mice. Int Immunopharmacol 76: 105886, 2019.

44. Chung HT, Pae HO, Choi BM, Billiar TR and Kim YM: Nitric oxide as a bioregulator of apoptosis. Biochem Biophys Res Commun 282: 1075-1079, 2001. 
45. Albert M, Corsilli D, Williamson DR, Brosseau M, Bellemare P, Delisle S, Nguyen AQ and Varin F: Comparison of inhaled milrinone, nitric oxide and prostacyclin in acute respiratory distress syndrome. World J Crit Care Med 6: 74-78, 2017.

46. Li JT, Wang WQ, Wang L, Liu NN, Zhao YL, Zhu XS, Liu QQ, Gao CF, Yang AG and Jia L: Subanesthetic isoflurane relieves zymosan-induced neutrophil inflammatory response by targeting NMDA glutamate receptor and Toll-like receptor 2 signaling. Oncotarget 7: 31772-31789, 2016.

47. Lossi L, Castagna $C$ and Merighi A: Caspase- 3 mediated cell death in the normal development of the mammalian cerebellum. Int J Mol Sci 19: 3999, 2018.

48. Li H, Wan A, Xu G and Ye D: Small changes huge impact: The role of thioredoxin 1 in the regulation of apoptosis by S-nitrosylation. Acta Biochim Biophys Sin (Shanghai) 45: 153-161, 2013.

49. Badshah H, Ali T, Kim MO: Osmotin attenuates LPS-induced neuroinflammation and memory impairments via the TLR4/NFkB signaling pathway. Sci Rep. 6: 24493, 2016.

50. Westphal M, Enkhbaatar P, Schmalstieg FC, Kulp GA, Traber LD, Morita N, Cox RA, Hawkins HK, Westphal-Varghese BB, Rudloff HE, et al: Neuronal nitric oxide synthase inhibition attenuates cardiopulmonary dysfunctions after combined burn and smoke inhalation injury in sheep. Crit Care Med 36: 1196-1204, 2008.

51. Sterner JB,Zanders TB, Morris MJ and Cancio LC: Inflammatory mediators in smoke inhalation injury. Inflamm Allergy Drug Targets 8: 63-69, 2009.

52. Fraunberger P, Grone E, Grone HJ and Walli AK: Simvastatin reduces endotoxin-induced nuclear factor kappaB activation and mortality in guinea pigs despite lowering circulating low-density lipoprotein cholesterol. Shock 32: 159-163, 2009.

53. Wassmann S, Laufs U, Bäumer AT, Müller K, Ahlbory K, Linz W, Itter G, Rösen R, Böhm M and Nickenig G: HMG-CoA reductase inhibitors improve endothelial dysfunction in normocholesterolemic hypertension via reduced production of reactive oxygen species. Hypertension 37: 1450-1457, 2001.
54. Nie Z, Deng S, Zhang L, Chen S, Lu Q and Peng H: Crocin protects against dexamethasone-induced osteoblast apoptosis by inhibiting the ROS $/ \mathrm{Ca}^{2+}$-mediated mitochondrial pathway. Mol Med Rep 20: 401-408, 2019.

55. Wang KS, Lv Y, Wang Z, Ma J, Mi C, Li X, Xu GH, Piao LX, Zheng SZ and Jin X: Imperatorin efficiently blocks TNF- $\alpha$-mediated activation of ROS/PI3K/Akt/NF- $\kappa B$ pathway. Oncol Rep 37: 3397-3404, 2017.

56. Mondal NK, Saha H, Mukherjee B, Tyagi N and Ray MR: Inflammation, oxidative stress, and higher expression levels of Nrf2 and NQO1 proteins in the airways of women chronically exposed to biomass fuel smoke. Mol Cell Biochem 447: 63-76, 2018.

57. Sun A, Wang W, Ye X, Wang Y, Yang X, Ye Z, Sun X and Zhang C: Protective effects of methane-rich saline on rats with lipopolysaccharide-induced acute lung injury. Oxid Med Cell Longev 2017: 7430193, 2017.

58. Kanugula AK, Gollavilli PN, Vasamsetti SB, Karnewar S, Gopoju R, Ummanni R and Kotamraju S: Statin-induced inhibition of breast cancer proliferation and invasion involves attenuation of iron transport: Intermediacy of nitric oxide and antioxidant defence mechanisms. FEBS J 281: 3719-3738, 2014.

59. Ferraro SA, Yakisich JS, Gallo FT and Tasat DR: Simvastatin pretreatment prevents ambient particle-induced lung injury in mice. Inhal Toxicol 23: 889-896, 2011.

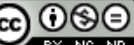

This work is licensed under a Creative Commons Attribution-NonCommercial-NoDerivatives 4.0 International (CC BY-NC-ND 4.0) License. 